\title{
WHEN IS SECESSION LEGITIMATE?
}

LAWS526: Comparative Constitutionalism

Submitted for the LLB (Honours) Degree

Faculty of Law

Victoria University of Wellington

2014 


\section{Contents}

I When is Secession Legitimate? ___ 4

A Introduction 44

B "A Territorially Concentrated National Group"

II Legal Legitimacy: Secession and International Law __ 8

A Decolonisation _ 8

B Non-colonial Secession __ 9

C Deficiencies __ 11

III Moral Legitimacy: Justifications for Secession ___ 12

A Introduction 12

B Primary Right Theories __ 13

$1 \quad$ An Ascriptive Primary Right (National Self-determination) ___ 13

2 A Right to Choose / Associative Theory__ 15

$3 \quad$ Limitations on the Primary Right ___ 17

$4 \quad$ Issues and Assessment ___ 18

C Remedial Right Theories __ 20

$1 \quad$ Serious and persistent breaches of human rights ___ 22

$2 \quad$ Past territorial grievance ___ 24

$3 \quad$ Persistent minority _ 26

$4 \quad$ General critique / support __ 28

IV Constitutional Legitimacy: Secession by Consent ___ 29

$V \quad$ When is Secession Legitimate? __ 31

A Developing Criteria __ 31

B Criteria for Assessing Legitimacy _ 31

$1 \quad$ Nationhood and Claim to Territory _ 32

$2 \quad$ Self-Determination and Autonomy __ 32

$3 \quad$ Treatment at the hands of the State

$4 \quad$ Viability of the proposed state __ 33

$5 \quad$ Position of the Existing State __ 34

C Summary 34

VI Application to Case Studies _ 35

A Scotland $\quad 35$

$1 \quad$ Nationhood and Claim to Territory _ـ 35

2 Self-Determination and Autonomy __ 35

$3 \quad$ Treatment at the hands of the State __ 36 
Viability of the proposed state 36

5 Position of the Existing State 37

$6 \quad$ Is Scotland's secession claim legitimate? 38

Catalonia 38

$1 \quad$ Nationhood and Claim to Territory 38

2 Self-Determination and Autonomy 38

3 Treatment at the hands of the State 39

$4 \quad$ Viability of the proposed state 39

$5 \quad$ Position of the Existing State 40

6 Is a Catalan secession claim legitimate? 41

C Eastern Ukraine 41

$1 \quad$ Nationhood and Claim to Territory 41

2 Self-Determination and Autonomy 42

3 Treatment at the hands of the State 42

$4 \quad$ Viability of the proposed state 43

$5 \quad$ Position of the Existing State 44

6 Is the Novorossiyan secession claim legitimate? 44

VII Conclusion 45

VIII Bibliography 47

\section{Word Count}

The text of this paper (excluding the cover page, table of contents, keywords, abstract, footnotes and bibliography) consists of exactly 14,989 words.

\section{Abstract}

Secession claims are not sufficiently dealt with at international law. Similarly theoretical analyses of the moral justifications for secession widely differ, with little scholarly agreement on, for example, whether there is a primary right to secede, a remedial right only, or no right to secede at all. This paper reviews the scholarly debate on legal, moral and constitutional legitimacy of secession, and develops five criteria for assessing the overall legitimacy of a secession claim: (1) nationhood and claim to territory; (2) selfdetermination and autonomy; (3) treatment at the hands of the state; (4) viability of the proposed state ; and (5) position of the existing state. Applying these criteria to three very different but equally topical possible secession claims - Scotland from the United Kingdom, Catalonia from Spain, and Novorossiya from Ukraine - the interplay between these criteria is demonstrated.

\section{Key Words}

Secession, Legitimacy, International Law, Scotland, Catalonia, Novorossiya 
There are estimated to be greater than 8000 "ethno-cultural groups" in the world, ${ }^{1}$ but there are less than 200 internationally recognised states. ${ }^{2}$ The vast majority of States are therefore described as "multinational states", whose boundaries encompass two or more national groups. ${ }^{3}$ The term Secession is a process by which a group of peoples (often referred to as "constituent" group, or "nation", or a colonial entity) withdraws from an existing, internationally recognised state, to create a new State on territory that was previously that of the existing state. ${ }^{4}$ The term covers numerous, widespread and varied political movements across countries and continents, in which national communities living within existing internationally recognised states assert their desire for the benefits of statehood in their own right. In 1992, Timothy Sisk identified such movements - those "seeking their own state or substantial autonomy" - in over sixty states, ${ }^{5}$ almost all of which continue in the present day.

As at 2014, active and serious secession movements include, among many others: Tamil Eelam in Sri Lanka; Donetsk in Eastern Ukraine; Flanders in Belgium; Kawthoolei in Southeast Burma/Myanmar; the Basque Country in Spain; Kurdistan in Iraq and the surrounding Middle East; Taiwan and Tibet in China; Barotzeland in Western Zambia; Kashmir in India; and Aceh Province in Indonesia. In the past several decades, there have been a number of successful secessions. While prior to 1990 the only successful attempt was the secession of Bangladesh (East Pakistan) from Pakistan, ${ }^{6}$ since that time the Soviet Union and Yugoslavia have broken down into a number of internationally recognised sovereign states, Eritrea has seceded from Ethiopia, East Timor has

\footnotetext{
${ }^{1}$ Badie, Bertrand, Berg-Schlosser, Morlino "International Encyclopedia of Political Science" (2011) SAGE knowledge at, at 3278 .

${ }^{2}$ Badie et al, above n 1 , at 3278 .

${ }^{3}$ Wayne Norman "Domesticating Secession" (2003) in Macedo and Buchanan Secession and Self-Determination (2003, NYU Press: NOMOS XLV, New York), at 3566, defines multinational as "states in which there is more than one group with a national self-consciousness, more than one group that considers itself to be a "people"."

${ }^{4}$ Badie et al, above n 1, at 3277; Aleksander Pavkovic and Peter Radan (eds) The Ashgate Research Companion to Secession (Ashgate, Australia, 2011) at 3; Prof Marcelo Kohen (ed) Secession. International Law Perspectives (Cambridge University Press, Cambridge, 2006), at 14.

5 Timothy Sisk Power sharing and international mediation in ethnic conflict (United States Institute of Peace, USA, 1996).

${ }^{6}$ Brilmayer, Lea, "Commentaries on Lea Brilmayer, Secession and Self-Determination: A Territorial Interpretation: One Decade Later" (2000). Faculty Scholarship Series. Paper 2439.

<http://digitalcommons.law.yale.edu/fss_papers/2439>.
} 
become independent from Indonesia, South Sudan has split from Sudan, and a number of other territories have declared their independence, to mixed receptions on the international political stage.

Modern conflict is increasingly taking place within state boundaries rather than between states. In many of these conflicts ethnic, cultural and religious divisions are at the root of the conflict, and a great number of these divisions also involve an unresolved territorial dispute. Badie et. al. write that: ${ }^{7}$

Given the countless unresolved cultural and territorial disputes and the many unsatisfied aspirations of nations in Africa, Asia and even in the West, for example, Quebec, Catalonia, the Basques, Flanders, Scotland, and Wales - secession continues to be a force to be reckoned with in international politics.

Recognizing the huge and widespread significance of that force, and the concerning dearth of agreement on when, where, and why secession should be allowed, this paper looks at the theoretical basis for secession. This is an area of legal scholarship in which there is vast disagreement, and a deep chasm between the work of lawyers and scholars, and what we see in practice on the international legal stage. Ultimately, this paper attempts to answer the question, 'when is secession legitimate?'.

After defining which groups are envisaged to have a legitimate secession claim, this paper begins at part II by traversing the international legal right to secede unilaterally in some circumstances. At international law, it is well established that colonial entities have a right to secede unilaterally and at will from their colonisers. There are international bodies in place to judge such claims, and recognised legal tests for determining who is entitled to such a right. The extent of the legal right, however, is not yet fully developed so as to include non-colonial situations. While recent state practice such as the recognition of Kosovo as an independent state by 108 states suggest that secession is not as unpalatable to existing states as previously thought, there is not yet sufficient consensus at international law as to when a sub-state group might have a right to secede. Accepting this deficiency at the international law level, it goes on to look at various theoretical justifications for secession. At part III, it looks at the moral justifications for unilateral secession - primary and remedial rights. ${ }^{8}$ Although I take the view that none of those theories alone provide a sufficiently complete moral justification for secession, elements of theorists work raise important questions that should be considered in a more full analysis of any secession claim, and thus are worked in to the

\footnotetext{
${ }^{7}$ Badie et al, above $\mathrm{n} 1$, at 2368.

${ }^{8}$ Allen Buchanan "Theories of secession" (1997) Philosophy and Public Affairs 26/1 31-61 at II.
} 
conclusions of this paper. At part IV, the paper addresses the virtually unquestionable right of a group to secede bilaterally by consent, and/or through a constitutional process, concluding that a consensual secession process should be allowed at international law.

From those bases, the paper attempts at part V to develop a criterion by which the legitimacy of any secession movement can be assessed. It concludes that there are five relevant criteria that should be considered when assessing a claim: (1) Nationhood / Claim to territory; (2) Self-Determination and Autonomy; (3) Treatment at the hands of the state; (4) Viability of the proposed state; and (5) Position of the existing state. The final part of the paper, part VI, goes on to apply that criterion to three timely and relevant case studies - Scotland in the United Kingdom, Catalonia in Spain, and Novorossiya in Ukraine.

\title{
B “A Territorially Concentrated National Minority Group"
}

Before discussing legitimacy, it must first be established to whom the justifications for secession might apply. Without definitively answering this question, which could constitute a separate essay in itself, this paper identifies a serious secessionist movement as a "territorially concentrated national minority group" (as well as abbreviated versions of that phrase) that has a clear desire to secede. The phrase was adopted from Badie et al, who wrote that:

\begin{abstract}
Multinational states are of central relevance for discussions of secession because virtually every serious secessionist movement in the past century has involved a historically rooted ethnocultural minority group with a national self conception ... Serious secessionist movements do not arise, for example, among groups of recent immigrants or within regions whose inhabitants identify with the larger nation. They arise among territorially concentrated national minorities, usually living within an historic homeland, more often than not within administrative boundaries (like a federal province) in which members of the group form a majority. ${ }^{9}$
\end{abstract}

There are three key elements of this term:-

(1) Uncontroversially, the group must be concentrated within a territory to which the group lays its claim. No serious secession claim can come from a group that is diffused across a state, or several states, and do not have a strong link to a particular territory. Charlotte Mueller writes, and this paper agrees, that "[a] precondition for an entity to secede would, thus, be the attachment to a fixed

\footnotetext{
${ }^{9}$ Badie et al, above n 1, at 3570
} 
territory. Furthermore, the group would have to demonstrate that its claim to the particular area supersedes that of the existing state." 10 As Badie et al identified, usually the territory will be a "historic homeland" of the members of the group, and often it will already exist as an identifiable administrative unit, such as a region or federal province.

(2) The group must be a minority within the existing state, such that they are unsatisfied with being governed by another (majority) group, but a significant majority in the territory on which they make their claim. A group that is not a minority within a state would not have any reason to desire secession, while a group that was not a majority in the contested territory would have no legitimate claim to govern.

(3) Most controversially, the group is referred to as a nation. The controversy arises on two fronts: firstly, the term nation, while commonly used in international law and political theory, is difficult to define; and secondly, a number of theorists would extend secession rights beyond nations. The term is defined along a number of lines - some consider that it has a distinctly ethnic meaning, others a civic definition, while some suggest a cultural conception. The true meaning of the term is, perhaps, an amalgamation of those concepts. Montserrat Guibernau, for examples, writes: "I define the nation as a human group conscious of forming a community, sharing a common culture, attached to a clearly demarcated territory, having a common past and a common project for the future, and claiming the right to rule itself", ${ }^{11}$ and similarly Charlotte Mueller identifies three essential characteristics of a nation: "Firstly, the existence of a shared overarching culture, secondly, an attachment to a certain territory and, thirdly, the striving for autonomy as a voluntary political community". ${ }^{12}$ The scholarly debate as to whether it is correct to limit secession to groups that have those characteristics is not yet settled. Allen Buchanan suggests, for example, that "all cultural groups" should be entitled to secession in certain limited circumstances, ${ }^{13}$ and Margalit and Raz recognise that "tribes, ethnic groups, linguistic, religious or geographical groups" may also be a "relevant reference point" from which secession rights should or could flow. ${ }^{14}$ The limitation to nations, however, is well justified by a number of theorists. Charlotte Mueller suggests that groups other than nations may struggle to establish a strong claim to territory, and agrees with David

\footnotetext{
${ }^{10}$ Charlotte Mueller "Secession and Self-Determination - Remedial Right Only Theory scrutinised" (2012) 7 POLIS Journal 283, at 294.

${ }^{11}$ Montserrat Guibernau Nationalisms: the Nation-State and Nationalism in the Twenty-first

Century (Cambridge, Polity, 1996) at 14.

${ }^{12}$ Charlotte Mueller, above n 10, at 293.

${ }^{13}$ Charlotte Mueller, above n 10, at 293.

${ }^{14}$ Avishai Margalit and Joseph Raz "National Self-determination” (1990) 87(9) Journal of Philosophy 439 , at 445.
} 
Miller ${ }^{15}$ and Kai Nielsen ${ }^{16}$ that "most nations on the contrary, have the ability to establish a strong claim to a territory, based on their historical roots." 17 According to Nielsen, it is this stronger claim that sets a nation apart from other groupings of people, as well as the greater likelihood that a nation, spurred by the force of nationalism, and by their historical and cultural ties to each other (a sense of belonging) and to the territory, that will "give force" to aspirations for political autonomy and self-government. ${ }^{18}$

\section{Legal Legitimacy: Secession and International Law}

\section{A Decolonisation}

In the last century, the international environment has undergone significant structural change, particularly in the area of Statehood. For example, "from 1947 to 1980, around 90 colonial entities, mostly in Asia, Africa and the Pacific, gained independence from European colonial powers and became sovereign states", including India, Nigeria and Indonesia, and outside that period many more new states have emerged. ${ }^{19}$ Although a number of states were created, it remains generally accepted that international law recognises only a very limited right to secede, ${ }^{20}$ solely applicable to the independence of colonised peoples. This is laid out in the 1960 UN Declaration on the Granting of Independence to Colonial Countries and People, in a number of United Nations resolutions, and has developed into a customary rule of international law. The custom allows the "granting of independent statehood to a colony which was usually not part of the territory of the metropolitan state and was usually separated from that state by a sea or an ocean." 21

In summary, it is custom at International Law that if a Colonial Entity (determined by the 'saltwater principle') wants to become independent, an automatic right to self-determination exists. According to the custom, however, any other group of peoples - including ethnic minorities, traditional nations, indigenous groups, etc - is not traditionally recognised as having access to the same right to independence. The International Court of Justice affirmed the existence of this legal right in: Accordance with international law of the unilateral declaration of independence in respect

\footnotetext{
${ }^{15}$ David Miller "Secession and the principle of nationality" in Margaret Moore (ed) National Self-determination and secession (Oxford University Press, Oxford, 2003) at 68.

${ }^{16}$ Kai Nielsen "Liberal Nationalism and Secession" in Margaret Moore (ed) National Self-determination and secession (Oxford University Press, Oxford, 2003) at 105-106.

${ }^{17}$ Charlotte Mueller, above n 10, at 295.

${ }^{18}$ Charlotte Mueller, above n 10, at 295; Nielsen, above n 16, at 105.

${ }^{19}$ Aleksander Pavkovic and Peter Radan, above n 4, at 2.

${ }^{20}$ Christopher Heath Wellman A Theory of Secession (Cambridge University Press, Cambridge, 2005) at 157.

${ }^{21}$ Aleksander Pavkovic and Peter Radan, above n 4, at 2.
} 
of Kosovo (Request for Advisory Opinion) (Kosovo Advisory Opinion). The Kosovo Advisory Opinion states that: ${ }^{22}$

During the second half of the twentieth century, the international law of self-determination developed in such a way as to create a right to independence for the peoples of non-selfgoverning territories and peoples subject to alien subjugation, domination and exploitation ... a great many new States have come into existence as a result of the exercise of this right.

The relevance of the 'salt-water test' is limited - indeed virtually redundant - in the modern international environment. ${ }^{23}$ As demonstrated by the proliferation of new states in the last century, the significant Colonial Empires - including the British, French, Belgian, German, Spanish, Portuguese, and Italian Empires - generally broke up in the 20th Century and (with a few exceptions, such as the Canary Islands, Dutch East Indies, and Gibraltar, among others) the majority of colonial entities have achieved independence or formed into new states made up of other neighbouring colonial entities. The focus on decolonisation is patently inapplicable to other types of self-determination dispute, particularly the territorially-concentrated minority populations that typify modern secession movements. The (controversial) question remains, then, whether the legal right to secede now extends beyond decolonisation. Despite lawyer's claims that there is no right beyond colonial entities, a number of new states have resulted from secession, even where the salt-water test did not apply. Examples of states that have received full international recognition include Bangladesh, Eritrea, Bosnia, Croatia, and more. ${ }^{24}$

Without attempting to provide a complete summary of international customary law, it is important to recognise that the nature of international customary law allows legal concepts to evolve with

\footnotetext{
${ }^{22}$ Accordance with international law of the unilateral declaration of independence in respect of Kosovo (Advisory Opinion) (2010) available online at International Court of Justice <www.icj-cij.org>, at 37.

${ }^{23}$ David McLean "Should I stay or should I go now? Secession and Self-Determination in International Law" (June 1995) Reocities < http://www.reocities.com/Athens/Agora/5465/Law/secession.html>, at D; Samuel J Spector, "Western Sahara and the Self-Determination Debate" (2009) Middle East Quarterly 33, at 33.

${ }^{24}$ David McLean, above n 23, at E.
} 
time. The term, as defined in the Statute of the International Court of Justice, ${ }^{25}$ refers to the obligations that arise where there is generally consistent practice of states (state practice) and an accompanying acceptance of a legal obligation (opinio juris). ${ }^{26}$ Accordingly, it is feasible that the custom relating to decolonisation and secession could have developed, be developing, or develop in the future to include non-colonial secessions as legally legitimate - an argument put forward by many legal scholars who recognise that in the future self-determination may become a legal norm. ${ }^{27}$

The 2008 Kosovo declaration of independence provides a valuable recent case study on state practice around unilateral secession. The Assembly of Kosovo declared its [Kosovo's] independence from Serbia, and was subsequently recognised as an independent state by a number of others, including the United States, United Kingdom, Germany and France. The International Court of Justice provided an Advisory Opinion answering the question "is the unilateral declaration of independence by the provisional institutions of self-government in Kosovo in accordance with international law?" 28 The majority of the Court advised that the declaration "did not violate any applicable rule of international law", but did not express any opinion on the result of the declaration. ${ }^{29}$ The court stated that: ${ }^{30}$

Debates regarding the extent of the right of self-determination and the existence of any right of "remedial secession", however, concern the right to separate from a State ... that issue is beyond the scope of the question posed by the General Assembly.

By Mid-2014, 107 of 193 UN member states have recognised Kosovo as an independent state though a number of other states have expressly refused to recognise its statehood. The implications of this case are widely contested. Some states, lawyers and theorists consider that Kosovo has now achieved independent statehood, and furthermore that "recent state practice, notably Kosovo's acquisition of independence in 2008, bolsters the view that, under exceptional circumstances, secession can be tolerated, justified or exculpated as an ultimo ratio in cases where 'internal' selfdetermination is persistently denied to a people." 31 Christian Walter argues, for example, that "even though the Kosovo Advisory Opinion did not expressly say anything on a right to secession" the

\footnotetext{
${ }^{25}$ Statute of the International Court of Justice, 18 April 1946, Art 38.

${ }^{26}$ Malcolm N. Shaw International Law (5th ed., Cambridge University Press, Cambridge, 2003) at 80.

27 Samuel J Spector, above n 23.

${ }^{28}$ Accordance with international law of the unilateral declaration of independence in respect of Kosovo, above $\mathrm{n} 22$, at $5 \mathrm{~S}$.

${ }^{29}$ Accordance with international law of the unilateral declaration of independence in respect of Kosovo, above $\mathrm{n} 22$, at 8.

${ }^{30}$ Accordance with international law of the unilateral declaration of independence in respect of Kosovo, above $\mathrm{n} 22$, at 8.

${ }^{31}$ Christian Walter, Antje von Ungern-Sternberg, and Kavus Abushov (eds) Self-Determination and Secession in International Law (Oxford University Press, Oxford, 2014), at 108.
} 
ruling that such a declaration was not illegal it no doubt "contributed to the international community's acquiescence to the developments in the specific case of Kosovo" and ultimately that "it cannot be excluded that a precedent for other cases was set." "32 Miroslav Jovanović also highlighted the precedent set by the Kosovo case, stating that "The Unrepresented Nations and Peoples Organisation, a group of some 70 members from Abkhazia over Kurdistan to Zanzibar, is and will be using the Kosovo precedent to pursue its objectives." 33 Others, however, refuse to accept that any precedent was created by Kosovo's declaration of independence, the court's advisory opinion, or the subsequent diplomatic relations of Kosovo.

\section{Deficiencies}

The breadth of state attitudes to a legal right to secede under exceptional circumstances was demonstrated in the written statements submitted to the ICJ for its consideration. A number of states suggested that the declaration could not result in independence for Kosovo as that would be contrary to international law; some suggested that a right to secede exists in some circumstances; and others suggested that secession is neither prohibited nor allowed by international law. It is difficult to readily accept as custom such a widely disputed action as secession. Perhaps the most palatable conception is that articulated by Christian Walter in 'The Kosovo Advisory Opinion: What it Says and What it Does Not Say' and similarly by Anne Peters in 'The Principle of Uti Possidetis Juris'. Walter's examination of the ICJ Advisory Opinion subtly praises what he terms the "judicial minimalism" of the court, in refusing to express any view on the legal effect of a declaration of independence - effectively removing that question from the legal realm. Likewise Peters suggests that "there is no right to secession ... that secession occurs within an international law free realm." 34 She points to the 'Principle of Effectiveness' at international law as meaning that "secession is a fact which imposes itself over the law" which will then be assessed on a case by case basis, by virtue of morality rather than legality.

As secession is a significant force in the current international environment, that situation is not sufficient. It is for this reason that this paper aims to amalgamate the different aspects of legitimacy of secession claims, to develop a set of criteria for assessing claims in a consistent manner. Overall, it is the author's view that much work is needed at an international level to bring secession into the realm of international law, and thus regulate state and sub-state behaviour.

\footnotetext{
${ }^{32}$ Christian Walter et al, above n 31 , at 108.

${ }^{33}$ Miroslav Jovanović The Economics of European Integration (Edward Elgar Publishing, UK, 2013) at 929.

${ }^{34}$ Christian Walter et al, above n 31, at 107.
} 


\section{Moral Legitimacy: Justifications for Secession}

The significant majority of legal scholarship around secession looks at the competing moral justifications for secession. Theorists approach the question of when secession is morally legitimate (and therefore a right should be recognised) in various different ways, attempting to establish when a secession claim is justified or unjustified. Badie et al. write that, "embedded in any secession lies the perceived justice of the community's cause." ${ }^{35}$ They suggest that "the debate surrounding the 'right of secession' ... revolves around (a) the argument that secession may be justifiable either in circumstances where state rule over a nation is particularly oppressive and tyrannical, or when a majority of a territorially concentrated community desires secession and (b) the argument that secession may be desirable due to the benefits it provides for nations to organise themselves according to their own values." 36 Importantly, the assessment of the justice of a particular claim is largely contingent on which side of the debate one falls. The important corollary to each argument is emphasised by Lea Brilmayer in her 1991 article. ${ }^{37}$ She, along with others including Allen Buchanan and Christopher Wellman, reminds us that secession is more than just the creation of a new state by a group - it is the taking of territory that is claimed by the existing state. ${ }^{38}$ The awareness that a secession claim "necessarily involves a claim to territory" 39 informs the assessment of any level of justice in secession.

Two categories of moral justification encompass much of the scholarly work that has been done in this area - here each of these categories are outlined, and assessed in light of recent case studies. At section B, primary right theories are outlined. These theories suggest that a distinct group (in either ascriptive or associative terms) has a general right to unilaterally secede, even where there is no injustice that requires remedying through independent statehood. Two subsets, (1) an ascriptive primary right or national self-determination theory and (2) a choice theory are described, along with a general assessment of the claims of such theories. At section $\mathrm{C}$, remedial right theories are addressed. Such theories generally suggest that a territorially concentrated national group may have a general right to secede unilaterally "if and only if it has suffered certain injustices, for which

\footnotetext{
${ }^{35}$ Badie et al, above n 1, at 3278 .

${ }^{36}$ Badie et al, above n 1, at 3278 .

${ }^{37}$ Lea Brilmayer "Secession and Self-Determination: A Territorial Interpretation" (1991) 16 Yale Journal of International Law 177.

${ }^{38}$ Lea Brilmayer, above $\mathrm{n} 37$ at 177-178.

${ }^{39}$ Christopher Heath Wellman "A Defense of Secession and Political Self-Determination" (1995) 24/2 Philosophy and Public Affairs 142, at 143; Allen Buchanan Secession: the Morality of Political Divorce from Fort Sumter to Lithuania and Quebec (Westview Press, USA, 1991) at 11.
} 
secession is the appropriate remedy of last resort" ${ }^{\prime 40}$. The theories are broken down into three types of injustice: (1) serious and persistent breaches of human rights and a threat to the nation's survival, (2) a past territorial grievance giving a legitimate territorial claim, and (3) the status of 'persistent minority' and refusal to grant or recognise any political autonomy to address that status.

\section{B Primary Right Theories}

Primary right theories suggest that a distinct group has a general right to secede unilaterally, effectively at will. Theorists such as Daniel Philpott and Harry Beran focus largely on national selfdetermination (ascriptive theory) and choice (associative theory) - if a group expresses a desire to secede, they have a moral right to do so. The right is justified as an extension of the democratic principle, and of the right of a nation to choose its government, despite tension between such a right and the principle of territorial integrity. ${ }^{41}$ The philosophical basis for such theories can be therefore summarised in simplistic terms as the view that government requires actual consent of its peoples, and that actual consent simply cannot exist where a group wishes to secede.

Primary right theories have failed to gain significant traction in the academic sphere, and are even less supported in diplomatic circles, where they are considered an affront to the international principle of territorial integrity and a threat to statehood. Even theorists who vehemently defend the moral right to secede by choice, for example Christopher Heath Wellman, recognise that "it remains highly controversial to suggest that a group might have a right to separate even when its state has in no way treated it unjustly", and further, where the group has no good claim to the territory in question. $^{42}$

The ascriptive 'primary right' theory "holds that certain groups whose memberships are defined by what are sometimes called ascriptive characteristics, simply by virtue of being those sorts of groups, have a unilateral claim-right to secede" 43 Ascriptive theories (at times referred to as "National SelfDetermination' theories of secession, as nationhood is generally the ascriptive characteristic upon which theories are based) suggest that any territorially concentrated national group will by virtue of being a nation, have a right to secede unilaterally and at will. Such theories rest heavily on the

\footnotetext{
${ }^{40}$ Allen Buchanan, above $\mathrm{n} 8$ at II.

${ }^{41}$ Daniel Philpott, and Harry Beran, cited in Margaret Moore National Self-Determination and Secession (1998, Oxford University Press, United Kingdom) at ch 1.

${ }^{42}$ Christopher Heath Wellman, above n 20, at 1.

${ }^{43}$ Allen Buchanan, above n 39, at 2.
} 
international legal concept of the right to national self-determination. That right, set out in the United Nations Charter and recognised as a fundamental principle of international law, is afforded to "all peoples". The definition of national self-determination is contested. Ascriptive or National Self-determination theorists consider that "all peoples" have the right to govern themselves, as independent political entities. They, according to Margaret Moore, "draw their conditions for secession from national self-determination ... suggesting that independence is justified by the importance of national identity". ${ }^{4}$

The foremost issue with ascriptive theories is the breadth at which they would apply secession rights. Charlotte Mueller writes that "ascribing a right to self-determination or even secession to all groups which would qualify as nations, as suggested by some scholars within the framework of "national self-determination" theories, implies a number of problems." The most important of these, she suggests is that "too great a number of groups would qualify as a nation, leading to numerous demands for independence and causing great instability". ${ }^{45}$ Likewise, Mavric Urska emphasises that "if we grant the right to secession to all ethnic groups just in virtue of them being ethnic groups, we are facing limitless fragmentation, and paralysis of the normal functioning of states", as there are "extremely many ethnic groups in the world". ${ }^{46}$ This concern is shared by Ernest Gellner, and further emphasised by David Miller. Miller suggests that "territories occupied by homogenous nations are very much the exception in today's world", and that giving such a broad right on purely ascriptive terms, with no other justification would be nonsensical. ${ }^{47}$ Such concerns may be somewhat overstated when one considers that not all nations or ethnic groups have a desire to secede (and in fact the vast majority do not). However, even with a less drastic take, the issue is somewhat valid.

A further issue with such theories is the contested nature of national self-determination as a right. It is now widely accepted at international law that self-determination does not confer a right of statehood on any nation that desires it, but is in fact much more limited. Aleksander Pavkovic and Peter Radan highlight that: "the quest for self-determination need not involve territory" and that the right "can be achieved either by affording them full citizenship rights or by granting them a special status under the host state's constitution." 48

\footnotetext{
${ }^{44}$ Margaret Moore (ed) National Self-determination and Secession (Oxford University Press, Oxford, 2003) at 7-8.

${ }^{45}$ Charlotte Mueller, above n 10, at 296.

${ }^{46}$ Urska Mavric "Rethinking the Right to Secession: A Democratic Theory Account" Central European University <www.etd.ceu.hu/2012/mavric_urska.pdf> at 25.

${ }^{47}$ David Miller, above n 15, at 66.

${ }^{48}$ Aleksander Pavkovic and Peter Radan, above n 4, at 13.
} 
Michael Seymour and Robert Nielsen, for example, suggest that at international law the right to self-determination applies to nations, giving each nation the right to internal self-determination, "understood as the ability for a people to develop itself within the encompassing state and to determine its own political status within the state" ${ }^{49}$. Christopher Borgen emphasises that: "so long as a state provides a minority group the ability to speak their language, practice their culture in a meaningful way, and effectively participate in the political community, then that group is said to have "internal self-determination." The vast majority of diplomats, lawyers and theorists have refused to recognise any ascriptive general right to secede on this basis. Generally, it is agreed that it is only in extraordinary circumstances (such as where internal self-determination is persistently denied) that such a right would extend to 'external self-determination', understood as independent statehood. ${ }^{50}$

Associative choice theories of secession without doubt represent the most radical or extreme discourse around secession. Such theories: "offer a voluntaristic justification for secession by maintaining that any group of individuals, located on a defined territory, has the right to secede and form a new state", if independent statehood is "the expressed desire of the majority of the entity's members". ${ }^{51}$ Put simply, any group that is concentrated in a territory can secede at will - the group is not required to meet the criteria for nationhood, though a nation would be afforded the same choice. The will of the majority, expressed through means such as a plebiscite on the question of independence, gives the group a primary right to exercise independence and secede from the existing state. Although choice theories do not focus on 'nationhood' as the defining characteristic of a legitimate secession movement, case studies tend to be national groups.

Choice based theories are strongly rooted in democratic theory. John Stuart Mill for example, laid out that "the question of government ought to be decided by the governed", introducing the idea that government is primarily about consent of the people. Perhaps the earliest choice theorist is Harry Beran, who supported the consent view. He suggested that the members of a group must consent to their political association / government, but that their consent is virtually revocable at

\footnotetext{
${ }^{49}$ Michael Seymour "Secession as a Remedial Right” (2007) 50 Inquiry 395 at 399.

${ }^{50}$ Charlotte Mueller, above n 10, at 292.

${ }^{51}$ Charlotte Mueller, above n 10, at 287. See also Anthony Pavkovic "Recursive Secession in Former Yugoslavia: too Hard a case for Theories of Secession" (2000) 48/3 Political Studies 485 at 486-487; F Deitrich "The status of Kosovo - reflections on the legitimacy of secession" (2010) 3/2 Ethics and Global Politics 123, at 127.
} 
will. ${ }^{52}$ Any territorial community - "a social group that has a common habitat, consists of numerous families ... and is capable of self perpetuation through time as a distinct entity" 53 - may exercise its right to secede. ${ }^{54}$ Diane Orenticher further emphasised the importance of consent to government. She wrote that, "the assumption that citizens provide ongoing, if tacit, consent to the boundaries of their state underpins the daily practice of democracy." 55 Her work then suggested that "if a significant, territorially bounded sub-group expresses its will to secede, the legitimacy of the state's sovereignty over the rebel population is placed in question" and secession should be considered as a viable option. ${ }^{56}$

Orenticher focussed heavily on the work of James Raskin. ${ }^{57}$ Raskin wrote that "The heart of the democratic idea is that governmental legitimacy depends upon the affirmative consent of those who are governed." 58 Orenticher suggested therefore that this core principle of legitimacy "might seem to be violated ... if they [the secessionists and rest of the existing state] were forced to remain cocitizens." 59 Orenticher discussed the movement in Quebec, Canada. She suggested that in the case of Quebec, "the consent of the people to be governed by the political authority that exercises sovereign power over them" is at stake. ${ }^{60}$ Orenticher's example, however, extended choice theory beyond simply the majority of Quebecers. She wrote that: ${ }^{61}$

Suppose that, instead of opposing Quebec separatists, the rest of Canada overwhelmingly voted in support of their claim. In this counterfactual, Canadians outside Quebec simply would not wish to be politically yoked to Quebec any longer. Suppose also that a vast majority of Quebec's citizens, including all of its significant minority populations, voted for secession. If, with Professor Franck, we believe that an emerging body of international law "requires democracy to validate governance" most of us would conclude that the mutual desire of Canada's citizens to divide should be honored - perhaps must be honored - in the absence of overrriding considerations.

\footnotetext{
${ }^{52}$ Harry Beran "A democratic theory of political self-determination for a new world order " in Percy B Lehning (ed.) Theories of Secession (Routledge, London, 1998) at 37-38.

${ }^{53}$ Harry Beran, above $\mathrm{n}$ 52, at 37-38.

${ }^{54}$ Harry Beran, above n 52, at 37-38.

${ }^{55}$ Diane F Orentlicher "International responses to separatist claims: are democratic principles relevant?" in Macedo and Buchanan Secession and Self-Determination (2003, NYU Press: NOMOS XLV, New York), at 27.

${ }^{56}$ Diane F Orentlicher, above n 55, at 26-27.

${ }^{57}$ Diane F Orentlicher, above n 55, at 26.

${ }^{58}$ Diane F Orentlicher, above n 55, at 26.

${ }^{59}$ Diane F Orentlicher, above n 55, at 26.

${ }^{60}$ Diane F Orentlicher, above n 55, at 26.

${ }^{61}$ Diane F Orentlicher, above n 55, at 25-26
} 
Choice theory, therefore, may also include considerations of the will of the majority of the existing state, depending on the conception of the democratic principle.

\section{$3 \quad$ Limitations on the Primary Right}

Both ascriptive and associative primary right theorists, recognizing the radicalness of their approaches, do not consider that the right to secede is unconstrained. Three key constraints are generally placed on the expression of the will to secede, as follows.

Firstly, most theorists recognise that a secession claim necessarily involves the taking of territory from the existing state. ${ }^{62}$ While some are unconcerned about territorial integrity in this way, many require at least some form of territorial justification for the claim. Although a much less rigorous justification is required here than that required by remedial right theorists, it is generally agreed that a group cannot claim to secede upon land which it has no connection. David Miller, a prominent choice theorists, applies a territorial criteria. His work recognises that the secessionists need to have a valid claim to the territory, but contends that this claim be determined by considering peoples as the "primary bearers" of territorial rights, rather than states. ${ }^{63}$ The question is thus, "do the people have a valid claim to the territory?', rather than 'does the state?'

Secondly, theorists suggest certain criteria that the proposed state must meet. Amandine Catala, for example, suggests that a group should perhaps be able to secede if the new state they propose will be 'politically legitimate'. She refers to political legitimacy in terms of providing adequate protection for human rights, internal self-determination, and protection of minority interests. Rather than limiting secession rights to groups within politically illegitimate existing states, she proposes "allowing secessionist groups that have not suffered a major injustice in the larger state but that would be able to provide adequate protection - as in the case of Quebec, for example - to fully exercise self-determination in creating their own state." 64 David Copp, a prominent supporter of the primary right to secede, suggests that an adjudication process carried out by the International Court of Justice should underpin the right - the court would consider whether there is in fact a desire to form a state, and whether the proposed state would be stable. ${ }^{65}$

\footnotetext{
${ }^{62}$ David Miller “Territorial Rights: Concept and Justification” (2012) 60/2 Political Studies 252 at 252.

${ }^{63}$ David Miller, above n 62, at 253.

${ }^{64}$ Amandine Catala "Remedial Theories of Secession and Territorial Justification" (2013) 44/1 Journal of Social Philosophy 74, at 75.

${ }^{65}$ David Copp "International Law and Morality in the theory of secession" (1998) 2/3 The Journal of Ethics 219, at 231-236.
} 
The third limitation placed on primary rights by a number of theorists is the impact of the secession on the existing state. Some theorists consider that a secession should be allowed if the existing state will remain stable and able to function after the territory and people are seceded from it. For example, the ICJ adjudication process suggested by Copp is also favoured by Christopher Heath Wellman, who referred to Copp's work as "a particularly sensible proposal". ${ }^{66}$ Wellman's primary right theory, includes further limitation, and in his view the court would be required "to determine whether both the separatists and the remainder state would emerge able and willing to perform the requisite political functions" of a stable independent state. ${ }^{67}$

\section{$4 \quad$ Issues and Assessment}

The primary right theories of secession are particularly radical, with significant implications for the principle of territorial integrity of states, and for the international political and juridical order. A general right to secede at will, without the consent of the existing state or any 'just cause' for the secession and where those states are carrying out their functions in a perfectly legitimate and just manner toward both the majority population and the secessionist minority, appears to go too far. A potential secession free for all could arise ${ }^{68}$ (although the limitations placed by many theorists would go some way to addressing this concern) and such a broad and general right does not reflect "the gravity of state breaking in our world". ${ }^{69}$ Lea Brilmayer has recently expressed strong opposition to such a right. ${ }^{70}$ In a political opinion piece on the proposed Crimean secession from the Ukraine, published in the Guardian, she stated that: ${ }^{71}$

It's a matter of international law: territory cannot be annexed simply because the people who happen to be living there today want to secede. If that were the case, then under international law, any geographically cohesive group could vote on independence. That would mean the Basques should be free from Spain and France, and the Kurds would have an independent nation; the large community of Cubans living in Miami could vote to separate from the United States.

This threat is again somewhat muted by the reality that not all such groups want to secede, and serious examples of secessionist movements will be limited in number. Using Brilmayer's

\footnotetext{
${ }^{66}$ Christopher Heath Wellman, above n 20, at 158.

${ }^{67}$ Christopher Heath Wellman, above n 20, at 158.

${ }^{68}$ Margaret Moore, above n 44.

${ }^{69}$ Allen Buchanen, above n 8, at IV.

${ }^{70}$ Lea Brilmayer "Why the crimean referendum is illegal" (14 March 2014) The Guardian <http://www.theguardian.com/commentisfree/2014/mar/14/crimean-referendum-illegal-international-law >.

${ }^{71}$ Lea Brilmayer, above $\mathrm{n} 70$.
} 
examples, this is clearly so, as there is no clear evidence that the Basques want independence, and Cubans in Miami is an even less practicable example. Aside from the threat to sovereignty and territorial integrity of existing states posed by such a broad general right to secede at will, several other issues arise. Firstly, the political order of existing states may be negatively effected. Albert Hirschman has famously suggested that too readily available secession may undermine political participation and involvement in the existing state for territorially concentrated minority groups, as those groups will see that if they are unsatisfied they are able to secede without issue. ${ }^{72}$ Secondly, too readily allowing secession without any assessment of the motivation for gaining independent statehood could give rise to political opportunism rather than addressing true nationalism, minority interests or remedying an injustice. Wayne Norman, for example, questions secession claims made by regions rich in natural resources, or with economies outperforming the rest of the existing state, ${ }^{73}$ in what Margaret Moore refers to as "a moral hazard". ${ }^{74}$ She writes that "rich regions that have no just cause to secede" are regarded with suspicion, as their claims are considered "vanity secession'. ${ }^{75}$ Rather than pointing to historical grievances or injustices, or even strong nationalism, arguably such secessions are motivated by political opportunism of elites within the minority, who seek to control the benefits of those natural endowments of the territory.

Overall, primary right theories are unlikely to sufficiently answer the question, when is secession legitimate?. In the current international legal framework, it is unlikely that existing states would be willing to recognise secessionist groups where they do not have "just cause" to secede unilaterally, particularly in terms of the precedent that recognition may set for groups within their own territories. For example, the Spanish government refuses to recognise Kosovo for fear of precedent setting for movements in Catalonia and the Basque Country. Allowing a general right to secede would impinge too far on territorial integrity and state sovereignty. Aspects of the theory, however, particularly the limitations placed on secession by theorists, provide important considerations for assessing secession claims in a more whole way.

\section{Remedial Right Theories}

\footnotetext{
${ }^{72}$ Albert O. Hirschman "Exit, Voice, and Loyalty" (1970, Harvard University Press, Cambridge).

${ }^{73}$ Wayne Norman "The Ethics of Secession as Regulation of Secessionist Politics" in Margaret Moore (ed) National Self-Determination and Secession (Oxford, Oxford University Press, 1998), at 55.

${ }^{74}$ Margaret Moore "Territorial Right and Secession: the problem of differential natural resource endowment" (unpublished) <http://eis.bris.ac.uk/ plcdib/territory/papers/Moore-TerritorialRightsandSecession.pdf $>$ at 1 .

${ }^{75}$ Margaret Moore, above n 74, at 1.
} 
Remedial right theories, perhaps the most prominent of which is outlined by Allen Buchanan in Theories of Secession (1997), view secession as a "remedy of last resort"76 or "last ditch response"77 to injustices. Theorists generally suggest that a territorially concentrated national / minority group will have a right to secede unilaterally from an existing state if the group has suffered certain serious injustices at the hands of the state, for which there is no other appropriate remedy. ${ }^{78}$ Such theories may also be described as 'Just Cause' Theories, insofar as they recognise a moral right to secede where a group has a just cause to do so.

The remedial rights idea has its roots in the work of classical natural law theorists. In The Law of War and Peace Hugo Grotius refused to recognise a general right of a group to unilaterally secede from a state, but permitted the right under extreme circumstances, where "it cannot save itself in any other way". ${ }^{79} \mathrm{He}$ conceded that in such a case, the group within the state "had a greater right to protect itself than the state had to retain sovereignty over the part." ${ }^{80}$ Lawyers and Modern theorists also draw on traditional theories of sovereignty and revolution, particularly those ideas espoused by John Locke in his Second Treatise of Civil Government. ${ }^{81}$ While Locke's work didn't expressly refer to rights of secession, his conception of the social contract and sovereignty "reserved a right of resistance" in certain circumstances. ${ }^{82}$ He suggested that a power is reserved to the people which allowed them to essentially dissolve and reconstitute their government should the existing government violate their mandate to govern by becoming tyrannical in nature. ${ }^{83}$ This was the "right to resume their original liberty, and by the establishment of a new legislative to provide for their own safety and security, which is the end for which they are in society". ${ }^{84}$ Remedial right theorists extend Locke's concept from the state level, to apply to "sub-state" regions "if severe injustices have been committed against the people inhabiting it". ${ }^{85}$ As did the classical theories, remedial right theories rely heavily on the balance of moral and political legitimacy of the existing state, rather than the legitimacy of the proposed or sought state. Modern legal theorists recognise that an existing state has a legitimate right to govern a people in a territory, even where those people are a national or political minority. Amandine Catala, for example, notes that "[remedial right] theories define political legitimacy ... as the state's adequate protection of human, territorial, autonomy, and

\footnotetext{
${ }^{76}$ Allen Buchanan, above n 8, at II.

77 Allen Buchanan, above n 8, at II.

78 Allen Buchanan, above n 8, at II.

${ }^{79}$ Stephen Neuff (ed) Hugo Grotius on The Law of War and Peace: Student Edition (Cambridge University Press, Cambridge, 2012) at 139. See also David McLean, above n 23, at E.

${ }^{80}$ David McLean, above $\mathrm{n} 23$, at E.

${ }^{81}$ Allen Buchanan, above n 8, at II.

${ }^{82}$ David Raic Statehood and the Law of Self-determination (Brill, Netherlands, 2002) at 307.

${ }^{83}$ Allen Buchanan, above n 8, at II. See also John Locke, Second Treatise of Civil Government (Hackett Publishing Co, Cambridge, 1980), at 100-124.

${ }^{84}$ John Locke, above n 83, at 307.

${ }^{85}$ Charlotte Mueller, above n 10, at 287.
} 
voting rights". She suggests that, "As long as a state provides such protection, it is just or legitimate, and therefore no group may permissibly secede from it." 86 Similarly, Allan Buchanan writes that, "the Remedial Right Only Theory begins with the presumption that existing states that are accorded legitimacy under international law have valid claims to their territories", but "argues that such claims can be overridden or extinguished in the face of persistent patterns of serious injustices towards groups within the state." ${ }^{~}$ Essentially, an existing state that is recognised as having legitimate statehood at international law and that provides adequate protection to its people, including its minorities, cannot be disavowed of its territory by a territorially concentrated minority group that desires self-determination.

Remedial right theorists agree, then, that secession will be legitimate if, and only if, certain injustices have been suffered by the territorially concentrated group that is seeking independence. This agreement does not extend, however, to any widely accepted treatise on what that injustice must be. At the most cautious end lie those who consider the remedial right as a response to large scale, persistent human rights violations against a territorially concentrated minority group, ${ }^{88}$ while less conservative theorists suggest that a just cause exists in any situation where the group has suffered a territorial grievance in the past. ${ }^{89}$ Wayne Norman's example set out five instances of injustice that would give rise to a remedial right to secede: ${ }^{90}$

(1) that it has been the victim of systematic discrimination or exploitation, and that this situation will not end as long as the group remains in the state; (2) that the group and its territory were illegally incorporated into the state within recent-enough memory; (3) that the group has a valid claim to the territory it wants to withdraw from the state; (4) that the group's culture is imperiled unless it gains access to all of the powers of a sovereign state; (5) that the group finds its constitutional rights grossly or systematically ignored by the central government or the supreme court.

In similar vein, Allen Buchanan identified three broad instances in which a right might exist as a measure of last resort: ${ }^{91}$

\footnotetext{
${ }^{86}$ Amandine Catala, above n 64, at 75.

${ }^{87}$ Allen Buchanan "Secession" (Feb 7 2003, revised Apr 5 2013) Stanford Encyclopedia of Philosophy $<$ http://plato.stanford.edu/entries/secession/> at 2.2.

${ }^{88}$ See for example, Allen Buchanan, above $\mathrm{n} 8$.

${ }^{89}$ See for example Lea Brilmayer, above n 37.

${ }^{90}$ Wayne Norman, above n 73, at 41.

${ }^{91}$ Allen Buchanan Justice, Legitimacy, and Self-Determination (Oxford: Oxford University Press, 2004).
} 
(a) large-scale and persistent violations of basic human rights, (b) unjust taking of the territory of a legitimate state (where secession is simply the taking back of wrongly taken territory, as with the secession of the Baltic Republics from the Soviet Union in 1991), and (c) in certain cases, the state's persisting violation of agreements to accord a minority group limited selfgovernment within the state.

Answering the question somewhat differently, Lea Brilmayer identified a single 'just cause' for secession:- "the possession of a historical claim that its territory was wrongfully annexed". ${ }^{22}$ For the purpose of this paper, I consider three justifications that could, according to certain theorists, give rise to a remedial right: (1) Serious and persistent breaches of human rights in the most extreme sense; (2) a past territorial grievance; and (3) the status of 'persistent minority'.

\section{$1 \quad$ Serious and persistent breaches of human rights}

The large scale, persistent breaches of fundamental human rights approach - as compared, for example, with the primary right and choice theories - is perhaps the most widely supported theory of secession, and explains a number of the successful secessions in the most recent century. The limited right is supported by Margaret Moore. ${ }^{93}$ She suggests that to avoid a secession free-for-all, which her work points to as likely creating a destabilizing effect on the international system and undermining the fundamental principles of state sovereignty and territorial integrity, secession must be limited. ${ }^{94}$ However, she recognises that in a few, very limited cases, it may be justified. Moore writes of remedial theories that: ${ }^{95}$

[the theory] suggests a strong internal connection between the right to resist tyranny (exploitation, oppression, genocide, wrongful seizure of territory) and the right to self- determination. By suggesting a strong link between the right to self- determination and human rights, this kind of argument grounds the right to self- determination within the generally accepted framework of human rights.

Allen Buchanan also supports this view. ${ }^{96}$ He states that "requiring serious grievances for legitimate secession creates a significant hurdle that reflects the gravity of state breaking in our world", and is therefore the only legitimate justification for unilateral secession by a territorially concentrated

\footnotetext{
${ }^{92}$ Lea Brilmayer, above n 37, at 283.

${ }^{93}$ Margaret Moore, above n 74.

${ }^{94}$ Margaret Moore, above n 74.

${ }_{95}$ Margaret Moore, above n 74, at 11.

${ }^{96}$ Allen Buchanan, above n 8.
} 
national group. ${ }^{97}$ The cautious, conservative remedial right approach significantly constrains the right to secede unilaterally, by requiring serious and persistent injustices effected on the secessionist population, by the state itself. ${ }^{98}$ The type of serious and persistent human rights abuses envisaged are those that threaten the existence of the minority group, which can clearly be attributed to acts of the existing state - for example gross systemic discrimination of the minority population, systemic exclusion from fundamental state provisions such as food and safe drinking water, and genocidal acts against the minority.

Two recent secession struggles would perhaps have qualified for a right to secede on this limited basis. The Kosovar (Kosovo Albanian) population in Serbia suffered gross human rights abuses at the hands of the Serbian government under the Milosevic regime, several years prior to its unilateral declaration of independence in 2008. Human Rights Watch, a non-government organisation that investigates and reports on human rights abuses around the world, published a 2010 report of evidence suggesting that the population had suffered executions, expulsions, rape and torture at the hands of the Serbian state police and military in 1998-1999. ${ }^{99}$ It is more than fathomable that these systemic human rights abuses and the threat to the Kosovar population go far in explaining the relatively wide acceptance of the region's unilateral declaration of independence, even though that declaration came outside the currently accepted framework of international law. Likewise, the Kurdish population in Northern Iraq suffered serious and persistent injustices at the hands of Saddam Hussein's regime. It is estimated that hundreds of thousands of Iraqi Kurds were killed, disappeared, tortured, raped and imprisoned in the late 1980s, and thousands of villages in the region destroyed during a process of ethnic cleansing. ${ }^{100}$ Following the United States invasion of Iraq in 2003, however, Iraqi Kurdistan has gained significant political and economic autonomy, and the persecution at the hands of the state government has ceased. ${ }^{101}$ It is therefore questionable whether the present-day independence movement could rely on serious human rights abuses as giving them a right to secede from Iraq:- in the words of Allen Buchanan, where the injustice is alleviated by a change of regime (or some other change), "it is no longer true that their only remedy for injustices is secession". ${ }^{102}$

\footnotetext{
97 Allen Buchanan, above n 8, at IV.

${ }^{98}$ Allen Buchanan, above n 39, at 2.

${ }^{99}$ Human Rights Watch "World Report Chapter: Serbia" (2010) Human Rights Watch < http://www.hrw.org/worldreport-2010/serbia-1>.

${ }^{100}$ Human Rights Watch, above n 99.

${ }^{101}$ Martin Fletcher "The Birth of Kurdistan” (August 2013) Prospect Magazine <http://www.prospectmagazine.co.uk/features/the-birth-of-kurdistan-martin-fletcher>.

102 Allen Buchanan Justice, legitimacy and self-determination: moral foundations for international law (Oxford University Press, Oxford, 2003) at 222.
} 
A right to secede on the basis of gross human rights abuses and a threat to the very existence of a minority population is quite unobjectionable. Limiting the right to only the most extreme of cases poses little threat to the international political / legal order, and doesn't undermine territorial integrity of existing states to an unacceptable degree. Furthermore, such a right may have the effect of incentivizing the "provision of justice" by states, or at least dis-incentivizing the commitment of genocidal acts and other systemic abuse and discrimination by internationally recognised states who wish to retain all their territory.

A different conception of the remedial right to secede suggests that such a right exists not only where the minority suffers systemic human rights abuses and a threat to ongoing existence, but also (or in some works, instead) where there has been "unjust taking of a legitimate state's territory"103, and the secession is simply the reclaiming of that territory, ${ }^{104}$ or where for some other reason, the group has a valid historical claim to the territory it wishes to secede. ${ }^{105}$

This justification formed the thesis of Lea Brilmayer's 1990 work, Secession and Selfdetermination, in which she suggested that "what makes a separatist movement's claim to independence convincing is the possession of a historical claim that its territory was wrongfully annexed". ${ }^{106}$ The territorial grievance justification explains, for example, the secession of the Baltic states - Lithuania, Latvia and Estonia - from the former Soviet Union, but arguably cannot explain the secession of Bosnia, Croatia and Slovenia from the former Yugoslavia. In each of the Baltic cases, the territory of a previously existing state had been forcibly seized, and annexed to the USSR. ${ }^{107}$ In the Yugoslav case, however, the states had voluntarily joined the union. Brilmayer links claims to independence of these kinds to the international legal acceptance of decolonisation explained earlier in this paper. She writes in a later paper that "[the 1950s and 1960s] wave of decolonisations was powered by the modern acknowledgement that earlier colonial annexations had been morally indefensible" and that the 1990s examples from the Baltic States and former Yugoslavia showed the extension of that moral judgement beyond colonial subjects to any annexed population. ${ }^{108}$

\footnotetext{
103 Allen Buchanan, above n 102, at 222.

${ }^{104}$ Allen Buchanan, above n 102; Lea Brilmayer, above n 37.

105 Wayne Norman, above n 73, at 55.

${ }^{106}$ Lea Brilmayer, above n 37, at 283.

107 Amandine Catala, above n 64, at 75.

${ }^{108}$ Lea Brilmayer, above n 6, at 283-284.
} 
Brilmayer's thesis focusses on "illegal annexation" as the key determinant of legitimacy of a secession movement, rather than on the rights of the people as a 'nation', or on any other injustice suffered by the people. She writes that: 109

... when a group seeks to secede, it is claiming a right to a particular piece of land, and one must necessarily inquire into why it is entitled to that particular piece of land, as opposed to some other piece of land - or no land at all.

Her thesis is convincing insofar as it justifies the territorial claim of the secession movement. As secession claims necessarily involve the taking of territory from an existing state, it certainly gives a claim the moral high ground if the secessionist group are able to prove that the territory would have been rightfully theirs, but for the illegal annexation.

Brilmayer, Norman and Buchanan suggest that requiring an illegal annexation (and in Buchanan and Norman's works either that or another sufficient injustice) would limit secession rights to only those with a just case. As David McLean emphasises, however, "there are virtually no secessionist or irredentist claims which cannot point to some territorial grievance at some time in the past." 110 Without limitation, such a justification may be open to a huge number of national groups claiming secession on the basis of their historical homeland, so as to undermine the territorial integrity of existing states. This is especially so where significant time has passed, the state or entity responsible for the illegal annexation or other territorial grievance is different to the current internationally recognised state with control over the territory, or actions have been taken by the state to remedy the grievance aside from affording independence.

\section{$3 \quad$ Persistent minority}

The third broad justification put forward for a remedial right to secession is the status of a group as a 'persistent minority'. This justification has inextricable links to both democratic theory and the right to national self-determination. Persistent minorities are described in democratic theory as a "vexing problem"111, where a minority group always finds itself at the losing end of any democratic decision. ${ }^{112}$ A persistent minority can also exist in a non-democratic state, where decisions by the state government are always averse to the will or interests of the minority. As

\footnotetext{
${ }^{109}$ Lea Brilmayer, above n 37, at 201.

${ }^{110}$ David McLean, above n 23, at E.

111 Tom Christiano "Democracy" (Jul 27 2006) Stanford Encyclopedia of Philosophy <http://plato.stanford.edu/entries/democracy/> at 5.3.2.

112 Tom Christiano, above n 111, at 5.3.2.
} 
Thomas Christiano emphasises, "being a persistent minority can be highly oppressive even if the majority does not try to act oppressively." 113 The implications for a territorially concentrated national minority group in this position are thus significant. In national self-determination terms, the status also limits the ability of the group to exercise its recognised right. As outlined previously, all nations have, at least, a general right to internal self-determination, "the ability for a people to develop itself within the encompassing state and to determine its own political status within the state". ${ }^{114}$ While this conception of the right to self-determination acts as a limitation on the ability of a territorially concentrated national group to assert a primary right to independent statehood, it may aid the same group's case for a remedial secession. If that group is a persistent minority, it may be said that in the "special circumstances", a right of 'external self-determination' in the sense of independent statehood may arise. ${ }^{115}$

Per the internal self-determination concept, there is a certain expectation that a territorially concentrated minority group will be afforded sufficient representation or political autonomy by the state. Within a democratic state, democratic rights and participation would ordinarily amount to representation, however where there is a persistent minority voting against the controlling majority it may not be sufficient. It is common practice for states to afford significant autonomy to such groups:- indigenous peoples and significant territorially concentrated national groups are often allowed, under provincial and federal arrangements, quite independent government and legislative powers on many matters. In the context of Canada's federal democracy, for example, the Quebec province is given more autonomy than other provinces, such as the ability to collect taxes, and authority over healthcare, education, immigration and employment policies. ${ }^{116}$ Furthermore, following political pressure, was recently recognised by the Canadian House of Commons as "a nation within a United Canada". In Scotland, significant political power is devolved to the Scottish national parliament - the Scottish Parliament and Scottish Government are currently competent to legislate for Scotland in all areas except those reserved to the Parliament of the United Kingdom (constitutional matters, international relations, trade and defence). ${ }^{117}$ Similarly, in Catalonia in Spain and Kurdistan in Iraq (as discussed earlier), like Quebec and Scotland, significant legislative and governing power has been devolved to the Regional Government. Such devolutions of power certainly undermine a group's ability to rely on its status as a minority to justify its secession.

\footnotetext{
113 Tom Christiano, above n 111, at 5.3.2.

${ }^{114}$ Michael Seymour, above n 49, at 4.

115 Charlotte Mueller, above n 10, at 289-290.

116 Sander Happaerts “Does Autonomy Matter” (2012) 45/1 Canadian Journal of Political Science 141 at 147.

117 Scotland Act 1998 (UK). See also Alexander Nicoll "Scotlands vote on Independence” (2014) 56/33 Survival:

Global Politics and Strategy at 105-120.
} 
Allen Buchanan suggests a further justification related to minority status and arrangements for autonomy. He writes that a remedial right may be available "in certain cases" where "the state's persisting violation of agreements to accord a minority group limited self-government within the state" undermines their internal self-determination. ${ }^{118}$ Secession conflicts and independence struggles, whether played out on political terms or as violent conflict, often lead not to independent statehood for the secessionists, but to agreements as to increased autonomy and limited selfgovernment of the type described above. Such agreements, however, are too often undermined by state's refusing to honour them. A pertinent example of this in practice is the situation between the Kosovar population and former Yugoslav state. The 1974 Yugoslav Constitution gave the Kosovo Province "de facto self-government" and recognised its autonomous status, but that constitutional recognition was repeatedly denounced and stripped in the intervening years, until international intervention reestablished autonomy in the region. ${ }^{119}$ The Kosovar population was, during that time subjected to gross human rights abuses at the hands of the state police and military, violent conflict in the Balkan region, and no consideration of the groups wishes or interests at government and legislative level. ${ }^{120}$ Despite the constitutional recognition, they were a persistent and oppressed territorially concentrated minority.

\section{$4 \quad$ General Critique / Support}

The remedial right theories of secession generally have more to recommend than the primary right theories, in that they do less to undermine the principles of territorial integrity and state sovereignty. Proving political legitimacy of the existing state and / or a territorial claim to the territory upon which the secessionists base their claim deals with a number of the concerns around state breaking and too readily allowing secession. Just cause theories would place significant limitations on the groups able to claim a right to secede unilaterally. For this reason, the author believes that any unilateral secession will be legitimate only if the secessionists are able to point to an injustice that will, in reality, only be remedied by independent statehood.

There are several important critiques of remedial right theories of secession. Firstly, the backward looking nature of the theories gives rise to concern that allowing a purely remedial right will fail to ensure stability and security, both within the proposed state and at inter-state level. Margaret Moore emphasises the risk involved in affording independence on a remedial basis. She suggests that "basing a right to secession solely on the experience of injustices ... entails the risk that newly

\footnotetext{
118 Allen Buchanan, above n 87, at 2.

119 Anonymous "Kosovo: the Problem" (1998) 22/4 World Eagle 31, at 31.

${ }^{120}$ Anonymous, above n 119, at 31.
} 
created states lack essential features of a functioning state." ${ }^{121}$ In later work she further suggests that "justice may be a good criterion for assessing government; but it does not seem to be the primary factor in understanding the quest to secede". ${ }^{122}$ Moore's critique on this basis is relatively robust. Affording secession rights to any territorially concentrated national (or in Allen Buchanan's case, cultural) group that has suffered the injustices laid about by remedial theorists is risky, if no consideration is given to the ability of that group to govern themselves. Addressing this concern might necessarily involve consideration of the limitations placed on secession by primary right theorists. A territorial claim, confidence of political legitimacy of the new state, and consideration of the ability of the existing state to remain stable and secure following secession would be just as well placed, if not more, in an application of a remedial right as a primary right. The second main critique of such theories is that they ignore the strength of nationalism, and the drive of communities, even those without legitimate justice based concerns, to govern themselves and determine their political order and future. ${ }^{123}$ On this point, Allen Buchanan recognises that: ${ }^{124}$

One cannot simply dismiss without argument the possibility that there can be circumstances under which a group living within the jurisdiction of the state may reasonably seek to achieve political autonomy for quite a different reason: to be able to express and sustain values other than, though not opposed to, justice, such as a distinct conception of community or a particular conception to religious life.

The strength of this critique is limited. While it is certainly important to recognise nationalism as a driving force behind secession claims, as previously addressed, there is limited merit in ascribing secession rights to all nations, simply to satisfy their nationalistic desires for self-determination. Particularly strong pure nationalistic claims, those that cannot point to any injustice to give the claim a just cause, may be dealt with through consensual secession processes (See IV) or may be sufficiently addressed with political autonomy at a lower level than outright independent statehood, for example through a permissive federal system, or recognition of autonomous regions with strong independent legislative and governing competencies.

\section{Constitutional Legitimacy: Secession by Consent}

\footnotetext{
${ }^{121}$ Charlotte Mueller, above n 10, at 302. See also Philpott "Self-Determination in Practice" in Margaret Moore (ed) National Self-determination and Secession (Oxford University Press, Oxford, 2003) at 82; Margaret Moore, above $\mathrm{n} 44$, at 6.

${ }^{122}$ Margaret Moore, above n 44, at 6

${ }^{123}$ Margaret Moore National Self-Determination and Secession (1998, Oxford University Press, United Kingdom).

${ }^{124}$ Allen Buchanan “Toward a Theory of Secession” (1991) 101/2 Chicago Law Review 322, at 325.
} 
While most scholarly discussion surrounds unilateral secession, it is important to address the legitimacy of consensual secession. Consensual secession is described by Allen Buchanan as "secession that results either from a negotiated agreement between the state and the secessionists" or through a constitutional process. ${ }^{125}$ It is generally agreed that a consensual secession is legitimate. David McLean, for example, writes that a "grant of independence ... in furtherance of the territory's self-determination" seems to give rise to an automatic secession right. ${ }^{126} \mathrm{He}$ suggests that such a grant is "a matter for domestic, not international law" and will be recognised as legitimate, in accordance with the state's sovereignty. ${ }^{127}$ There are a number of examples of consensual secessions. The break up of Sweden and Norway in 1905, and the Constituent Republics of the former Soviet State, who were granted secession rights, as allowed in the Soviet constitution are examples of secessionist states that are now fully recognised as independent states. Because consensual secession processes are agreed upon by the existing state, such secessions are less radical than unilateral claims. The territorial integrity and sovereignty of the state are not undermined, and legitimacy concerns are thus much lesser.

There are few states in the world that include an explicit mechanism for secession within their constitution - the Soviet constitution contained a clause, ${ }^{128}$ and the 1995 Ethiopian constitution contains a provision stipulating "every nation, nationality and people shall have the unrestricted right to self-determination up to secession", and sets out the process through which secession can be achieved. ${ }^{129}$ Even in states without such provisions, there is a possibility of a consensual secession process, enacted within the constitutional structure of the state. Constitutionalising secession in this manner was in large part the focus of the Supreme Court of Canada in Reference re Secession of Quebec. ${ }^{130}$ The highest Canadian court was asked to consider: ${ }^{131}$

1. Under the constitution of Canada, can the National Assembly, legislature or government of Quebec effect the secession of Quebec from Canada unilaterally?

[and]

2. Does international law give the National Assembly, legislature or government of Quebec the right to effect the secession of Quebec from Canada unilaterally? In this regard, is there a right

\footnotetext{
${ }^{125}$ Buchanan, above n 87.

${ }^{126}$ David McLean, above n 23, at E.

${ }^{127}$ David McLean, above n 23, at E.

${ }^{128}$ Cass Sunstein "Constitutionalism and Secession" (1991) 58/2 The University of Chicago Law Review 633.

${ }^{129}$ Constitution of the Federal Democratic Republic of Ethiopia, 21 August 1995, Art 39.

${ }^{130}$ Reference re Secession of Quebec [1998] 2 S.C.R. 217 at 1.

${ }^{131}$ Reference re Secession of Quebec, above $\mathrm{n} 130$, at 1.
} 
to self-determination under international law that would give the National Assembly, legislature or government of Quebec the right to effect the secession of Quebec from Canada unilaterally?

The court held, essentially, that Quebec had no right to secede unilaterally from Canada. ${ }^{132}$ "Quebec could not", even by a significant majority vote in a referendum, "purport to invoke a right of self-determination to dictate the terms of a proposed secession to the other parties to the federation [the rest of Canada]". ${ }^{133}$ However, it recognised that if a "clear majority" of Quebecers expressed a wish to secede from Canada, a legitimate process of negotiation in line with the constitutional order of Canada could be invoked to allow secession by consent. ${ }^{134}$ This constitutionally based analysis of the secession issue is, according to Allen Buchanan: ${ }^{135}$

\begin{abstract}
... remarkable, not only because it is exceptionally well reasoned and lucid, but also because it attempts to do something of great importance that has not been done before: to subject the potentially destructive issue of secession to the rule of law by constitutionalising the secession process, but in the absence of an existing explicit constitutional provision for secession. (emphasis added)
\end{abstract}

The approach of the Canadian court is transferrable to other jurisdictions, and has indeed been seen in practice on several occasions. Although a constitutional secession process would look different $\mathrm{n}$ the context of different states and constitutional structures, the underlying theme of constitutional legitimacy exists irrelevant of the exact constitutional order.

The sole legitimacy issue that arises in relation to consensual processes is the stability and viability of the proposed state, and the continued stability and viability of the existing state. South Sudan, for example, achieved independence from the Republic of Sudan in 2011 with the consent of the Sudanese government. The new state has since that time continued to descend into civil war. Although the South of Sudan was dissatisfied with the Sudanese state, the region was arguably not unified or prosperous enough to create a peaceful and viable state.

\title{
V When is Secession Legitimate?
}

\section{A Developing Criteria}

\footnotetext{
${ }^{132}$ Reference re Secession of Quebec, above n 130, at 1.

${ }^{133}$ Reference re Secession of Quebec, above n 130, at 1.

${ }^{134}$ Reference re Secession of Quebec, above n 130, at 1.

${ }^{135}$ Allen Buchanan “The Quebec Secession Issue: Democracy, Minority Rights, and the Rule of Law” in Macedo and Buchanan Secession and Self-Determination (2003, NYU Press: NOMOS XLV, New York), at 4414.
} 
The aim of this paper has been to develop a set of criteria by which the legitimacy of a secession movement / claim can be assessed. After reviewing the scholarly debate around legitimacy of secession, it is clear that each of the theories has elements to recommend, as well as issues. The following criteria is an attempt to amalgamate the divergent discourse into a set of factors to be considered, on a case by case basis, to gauge the legitimacy of a secession. If it is good, the criteria should be sufficient to assess virtually any movement or independence claim that arises.

\section{B $\quad$ Criteria for Assessing Legitimacy}

Five areas must be considered in assessing a claim: (1) Nationhood / Claim to Territory; (2) Selfdetermination and Autonomy; (3) Treatment at the hands of the state; (4) Viability of the proposed state; and (5) Position of the existing state.

\section{$1 \quad$ Nationhood and Claim to territory}

As previously outlined, it is the author's view that secession rights should be limited to territorially concentrated national groups. The group must be attached to a fixed territory, which forms the subject of the secession claim. It is important that the attachment is identified, as a group will not be able to legitimately deprive an existing state of part of its territory arbitrarily. The strength of the territorial claim will depend on several considerations. If the group can establish that the land was wrongfully annexed to the state, as Lea Brilmayer described, their territorial claim will be strong. However even if they cannot prove that, an attachment to the land in the sense of it being a historical homeland for the national group may be legitimate in some instances. A group's territorial claim will also rest on the significance of that group within the territory claimed. A virtually homogenous territory where support for independence is very high, will without doubt have a more significant territorial claim than a group with a bare majority in the territory that includes a number of nationalities, or where support for independence is low or average.

\section{$2 \quad$ Self-Determination and Autonomy}

As discussed, it is an accepted principle of international law, both in custom and enshrined in various international instruments, that all nations have the right to national self-determination. Although it is the subject of some scholarly and diplomatic debate, it is generally accepted that in ordinary circumstances, this right will be respected if a national group is given sufficient internal 
self-determination. An important consideration for any secession will thus be the selfdetermination afforded to the secessionist group, and the respect given by the existing state of the group's right.

In a rights respecting, representative democracy it will often be sufficient that a group is represented at the state level - for example through meaningful participation in elections, regional representatives in parliament, and insurances of minority protection are all measures present in democratic state bodies. Particularly strong or vocal nations within larger states may demand greater levels of autonomy, and it is relatively common international state practice to afford such groups significant autonomy. Likewise, where the nation finds itself in a persistent minority position that greater level of autonomy may be required to address the democratic problem. Where internal self-determination is afforded in this way, it is less likely that a group can make a legitimate secession claim. In the same vein, where a group is not afforded any internal self-determination their claim will certainly gain legitimacy. For example where the group are not sufficiently represented at state level (at the most extreme, where they are denied political participation rights, or are located within a non-democratic state) or find themselves in a persistent majority position, and the state refuses to afford any autonomy over regional decision making, their claim will have a much stronger basis in international law. Further, as Allen Buchanan suggested, where autonomy arrangements are in place, but persistently are not respected by the state, the same will be true.

\section{$3 \quad$ Treatment at the hands of the state}

In accordance with the view that the remedial right theories of secession provide the strongest justification for state breaking, particularly as against the important principles of territorial integrity and state sovereignty, the treatment of the secessionist group at the hands of the existing state will be relevant to the legitimacy of their claim. A poorly treated territorially concentrated national group will generally have a stronger claim. At the most extreme end of the spectrum, genocidal acts by the state or threats of such acts would likely give a group an urgent claim of legitimacy as a matter of self defence. Other gross or persistent breaches of human rights, especially those systemically targeting the group's population and threatening the ongoing survival of the nation, would also suggest a legitimate secession claim can be made by the group. Lesser examples of poor treatment of the group by the state, and groups that cannot point to any injustice at the hands of the state may struggle to make out a legitimate claim. 
A legitimate secession claim must involve an assessment that the proposed state will be viable immediately following the secession, and in the long term. Relevant considerations include the expected political stability of the proposed state, the economic viability of the region without the support of the existing state, and the likelihood that the proposed state will be politically legitimate. A secession claim that is genuinely supported by the population of the territory claimed, and won't be likely to result in further conflict within the proposed state or the perpetuation of new minority groups, will be more legitimate than a claim that cannot offer these assurances. Furthermore, a territory endowed with a strong economy and rich in natural resources will be more likely to be economically viable than a poor region with low levels of economic performance - though this must of course be balanced against the risk of such prosperous regions seeking 'vanity secessions', as discussed previously. As the secession generally involves severing economic ties with the existing state, however, it is important that the region can afford to do so both in the short and long term. Finally, the proposed state must be politically legitimate, in the sense that it provides adequate protection for human rights, including the rights of any minorities within the new state. Secession will not be legitimate where the proposed state is unlikely to be any more respecting of fundamental human rights and freedoms than the existing state, where the position of its occupants will be negatively impacted by secession, or where its creation is likely to result in significant internal conflict.

As secession involves a hostile territorial claim against the existing state, and is likely to have a significant impact on that state, a final consideration must be the position of that state. As explained at IV, where the existing state consents to the secession of the territory it is unlikely that the claim will not be considered legitimate. In such an instance, only serious concerns about the viability of the proposed state would be likely to undermine the legitimacy afforded by the consensual process. Where the existing state does not consent to secession, the interest of that state must be considered. The existing state must be able to continue to perform its functions of statehood and remain economically viable. For example, the secession of a large portion of the existing state's territory, taking significant economic resources and wealth, may leave the greater state with significantly lesser economic stability. If that secession would be ruinous to the existing state, it cannot be considered legitimate.

\section{Summary}


As secession is such an extreme response by a group, and because the nature of secession movements is so varied, each secession claim should be assessed independently and on its merits. Importantly, each of the above criteria cannot generally be taken alone to legitimise a secession claim. Legitimacy is a question of balancing the relevant factors to holistically assess the claim. Indeed, a strong or indeed decisive factor in one case may be a significantly lesser factor in another where the stakes are vastly different.

For example, a legitimate secession claim will likely exist in the following example: A nation resides in a virtually homogenous territory that is recognised as the group's traditional homeland, the group is afforded representation at a state level but little in the way of regional / territorial autonomy. Although there is no particular human rights abuse or grievance at the hands of the state that it can point to, the group's interests are consistently ignored in state decision making, suggesting that the group is a persistent minority. The region has a reasonably strong economy and average resource endowment, and would likely be able to carry out the requisite functions of a state even if it was independent, and the secession would not have a significant impact on the GDP or other economic performance measures of the existing state. The legitimacy of the claim would be much less, however, if the region was afforded greater self-determination by the state thereby sufficiently addressing its status as a persistent minority, and removing its justification for seceding. Likewise, if the region would have little prospect of economic stability the legitimacy of its claim would be significantly dampened. Although these criteria may appear to give quite significant power to an existing state, the interplay between criteria also places obligations on those states and allows for recourse in the most extreme circumstances. The application of these criteria will be further explained at VI, where they are used to assess three possible secession claims: Scotland from the United Kingdom, the Donetsk Region from Ukraine, and Catalonia from Spain.

\section{Application to Case Studies}

\section{A Scotland}

\section{$1 \quad$ Nationhood / Claim to territory}

Since 1707, Scotland - along with England, Wales and Northern Ireland - has been a part of the United Kingdom. Prior to that amalgamation, the Kingdom of Scotland was an independent state. It has a strong national identity and cultural association as a people, including competing in its own 
right in international sporting and other competitions. It therefore meets the requirement of nationhood, and although it cannot point to a recent territorial grievance, has a good historical claim to the territory as its traditional homeland.

A significant amount of political power is devolved to its national parliament - the Scottish Parliament and Government are currently competent to legislate for Scotland in all areas except those reserved to the Parliament of the United Kingdom (constitutional matters, international relations, trade and defence). ${ }^{136}$ There have been reasonably strong calls for Scottish independence in recent history, with referendums on devolution held in 1979 and 1997 resulting in the Scotland Act 1998. However, despite the significant autonomy, in 2014 Scottish secession is a live and relevant issue.

\section{$3 \quad$ Treatment at the hands of the state}

The United Kingdom is a constitutional democratic state, with a strong human rights record including recourse to the European Court of Human Rights in the event of any alleged breach. The Scottish people are not systemically discriminated against, and cannot point to any rights related grievance. Furthermore, they are strongly represented at legislative and government level, and Scottish representatives in the Houses of Parliament often have significant influence on the outcomes of legislative decisions. There is no threat to the survival of Scottish people or culture should the nation remain within the United Kingdom, and thus no remedial justification for urgent secession.

\section{$4 \quad$ Viability of the proposed state}

Scotland would likely be a viable independent state if it was to secede from the United Kingdom. The region has a reasonably strong economy, underpinned by manufacturing, heavy industry, oil extracting and increasingly service related industries. ${ }^{137}$ It is a strong exporting nation. Although independence may have some impact on its exports and petroleum industries, dependent on the terms negotiated with the United Kingdom Government and acceptance into the European Union,

\footnotetext{
${ }^{136}$ Scotland Act 1998 (UK). See also Alexander Nicoll "Scotland's vote on Independence" (2014) 56/33 Survival: Global Politics and Strategy 105.

${ }^{137}$ Scottish Government "Monthly Economic brief - July 2014” (31 July 2014) The Scottish Government <http://www.scotland.gov.uk/Topics/Economy/Monthly-Economic-Brief>.
} 
its economic position would allow it to carry out the functions of statehood and would not hugely influence the position of its people. Furthermore, there is no suggestion that an independent Scotland would be politically illegitimate, that its human rights record would deteriorate, or that minorities within Scotland would be persecuted. In fact, the Scottish National Party has indicated that an independent Scotland would entrench the European Convention on Human Rights, and this has been incorporated in the interim constitution proposed by the Scottish Government. ${ }^{138}$

The independence debate has culminated in the Parliament of the United Kingdom granting Scotland the right to hold a referendum on independence through "the Edinburgh Agreement", beginning a process by which Scotland may ultimately secede in a constitutionally legitimate fashion. ${ }^{139}$ The referendum is set to take place on 18 September 2014, and will ask "Should Scotland be an independent country?" Following a yes vote (should this result), negotiations are planned between the governments of Scotland and the United Kingdom to set "the parameters for Scotland's transition to independence", including the timetable and process, and the "constitutional platform - laws and administrative arrangements to establish Scotland as an independent state". ${ }^{140}$ The agreement between the parties effectively commits the United Kingdom Government to engage in negotiations in good faith. ${ }^{141}$

A "yes" outcome would "fundamentally alter the British Isles", ${ }^{142}$ but the process through which it occurs - initiated through cooperation, put to a democratic decision making process, and ultimately hashed out through negotiations, with respect for the fundamental tenets of the United Kingdom's unwritten constitutional structure, and put into place with the consent of the Scottish peoples, the United Kingdom government from which they are seceding, would inarguably have constitutional legitimacy far above any unilateral attempt at secession. Stephen Tierney applied the Supreme Court of Canada's approach to the Quebec question (discussed in this paper at IV) in the Scottish context, suggesting that the legitimate nature of the process would "greatly assist an independent

\footnotetext{
138 Scottish Government "The Scottish Independence Bill: A Consultation on an Interim Constitution for Scotland" (2014) Scottish Government <http://www.scotland.gov.uk/Resource/0045/00452762.pdf $>$, at Arts 26-28.

139 "Agreement between the United Kingdom Government and the Scottish Government on a referendum on independence for Scotland" (15 October 2012) Scottish Government

<http://www.scotland.gov.uk/Resource/0040/00404789.pdf>; Scotland Act 1998 (Modification of Schedule 5) Order 2013 (UK) (S.I. 2013/242).

140 Scottish Government "FAQ" (2014) Scotland's Referendum <http://www.referendum.scot>.

${ }^{141}$ Steven Tierney "Legal Issues surrounding the Referendum on Independence for Scotland" (December 2013) 9/3 European Constitutional Law Review 359.

${ }^{142}$ Alexander Nicoll, above n 136.
} 
Scotland in the search for early international recognition". ${ }^{143}$ Accordingly, the cooperation of the United Kingdom Government with the Scottish Independence movement, means that the resultant "negotiated independence" is not expected to face the same international objection that is seen when states attempt succession unilaterally, as there is a significant legitimacy gain. ${ }^{144}$

Having applied the five criteria for legitimacy, it is clear that a secession claim by Scotland would be legitimate. Although it cannot point to any remedial justification for seceding from the United Kingdom (either through a lack of self-determination or poor treatment at the hands of the United Kingdom), the consensual nature of the possible secession means that such a justification is not strictly necessary. Furthermore, the Scottish people are a strong, territorially concentrated national group, with a good claim to the territory of Scotland. There is no reason to believe a Scottish state would not be viable, economically or politically.

\section{B Catalonia}

$1 \quad$ Nationhood / Claim to territory

Catalonia is an autonomous community of Spain. It has a distinct ethnic and linguistic identity from the majority of Spain. ${ }^{145}$ As with several other regions within Spain, there is a strong nationalist movement among the Catalan people, including an increasing drive for complete independence from Spain. ${ }^{146}$ Historically, Catalonia was an independent principality, but conflict in the region resulted in the region being amalgamated with Spain. ${ }^{147}$ Although the territory was

\footnotetext{
${ }^{143}$ Steven Tierney, above n 141 , at 378.

${ }^{144}$ James Crawford and Alan Boyle, "Opinion: Referendum on the Independence of Scotland - International Law Aspects" published in annex to UK Government Devolution and the implications of Scottish Independence (UK Government, London, 2013) at para 90.

${ }^{145}$ Monteserrat Guibernau “The rise of secessionism in Catalonia has emerged out of the will to decide the region's political destiny as a nation" (2012) European Politics and Policy Blog

<http://blogs.lse.ac.uk/europpblog/2012/05/29/catalonia-secession/>.

146 Montesserat Guibernau "Prospects for an Independent Catalonia" (2013) International Journal of Politics, Culture and Society 27/1, 5-23, at 18, writes that empirical data from Barcelona indicates that "In 2011, 42.9\% of Catalans stood in favour of independence to the question 'if tomorrow there was a referendum to decide on Catalan independence, how would you vote?' In December 2012 support for independence rose to 57 \% (CEO, 2012). In June 2013, there was a slight decline; $55.6 \%$ indicated that they would cast a 'yes' vote for Catalan independence. At the same time, $23.4 \%$ said that they would vote against and $15.3 \%$ would abstain or would not vote (CEO, June 2013). Data from madrid shows similar results.

147 The Economist "Centrifugal Spain: Umbrage in Catalonia" (Nov 24 2012) The Economist <http://www.economist.com/news/leaders/21567088-even-though-spectre-secession-unwelcome-distraction-spain-stillneeds $>$.
} 
disputed for many years, Catalonia adopted the 1978 Spanish Constitution, thus remaining part of Spain.

Like Scotland, significant legislative and governing power has been devolved to the Regional Government in Catalonia. The government of the autonomous community, the Generalitat, legislates on local government, justice, culture, environment, health, commerce, education, transport, and many other matters. ${ }^{148}$ A 2012 editorial in the economist (author unknown) emphasised that "Under Spain's constitution of 1978, Catalonia enjoys more self-government than almost any other corner of Europe." 149 Despite that, there are strong calls for independence in Catalonia. ${ }^{150}$

In relatively recent history, the Catalan people and culture were treated poorly at the hands of the Spanish government. ${ }^{151}$ Under the Franco regime, Catalan language was banned and cultural institutions were abolished, and many other measures to repress the distinct national identity were implemented by the Dictatorial government. ${ }^{152}$ Since the mid-20th Century, however, such measures have been reversed, particularly with the increasing autonomy afforded to the region. The current Spanish state is quite distinct from the previous regime, and the actions of that regime cannot provide any remedial justification to secede.

Absent of such a remedial right, the movement is at the moment driven predominantly by economic performance of the region: It contributes around twenty percent of the Spanish Gross Domestic Product; is a strong exporting region; and consistently performs more strongly than the rest of Spain in economic indicators. ${ }^{153}$ Other contributing factors include historical disharmony, current day tensions between the governments in Barcelona and Madrid, and the poor performance of Spain on the international stage. ${ }^{154}$

\footnotetext{
148 The Economist, above n 147.

149 The Economist, above n 147.

${ }^{150}$ Montesserat Guibernau, above n 146, at 18.

${ }^{151}$ Josep Desquens "Europe's stateless nations in the era of globalization: the case for Catalonia's Secession from Spain" (2003) The Bologna Center Journal of International Affairs <http://www.jhubc.it/bcjournal/articles/desquens.cfm>.

152 Josep Desquens, above n 151.

${ }^{153}$ Montesserat Guibernau, above n 146, at 15.

${ }^{154}$ Montesserat Guibernau, above n 146, at 15.
} 
The viability of an independent Catalonia is strongly contested. As mentioned above, Catalonia has a relatively strong regional economy in comparison to the rest of Spain, and like Scotland, is an export-driven economy. ${ }^{155}$ Proponents of Catalan independence suggest that an independent Catalan would be economically better off, as it would no longer have to support the poor regions in Spain. Others suggest, however, that the region is too small, would have a significant debt burden, and has little in the way of natural resources. ${ }^{156}$ Politically, there is no reason to believe a Catalan state would be illegitimate, oppressive or non-rights respecting.

The Spanish government refuses to consent to secession by Catalonia. The 1978 Spanish Constitution, created following the end of the Spanish Civil War, emphasises principles of unity, majoritarian democracy, constitutionalism and territorial integrity. ${ }^{157}$ It addresses the ethnic and national divisions within Spain at Article Two, stating: ${ }^{158}$

The Constitution is based upon the indissoluble unity of the Spanish Nation, the common and indivisible patria of all Spaniards, and recognises and guarantees the right to autonomy of the nationalities and regions that make it up and solidarity between all of them.

Guibernau writes that this article "reveals the tension between defending the unity of Spain" and "pressure for the historical nationalities of Catalonia, Galicia, and the Basque Country to be recognised". ${ }^{159}$ In light of this constitution, the Spanish government has refused to allow any claim for sovereignty to gain legitimacy and rejected a proposal for a binding referendum in early 2014, and the Spanish Constitutional Court ruled in 2010 that "Sovereignty is not contemplated in our constitution for nationalities and regions that make up the state" and that the principle of "indissoluble unity of the Spanish Nation" cannot be undermined in any circumstances, such as by a secession referendum or negotiations between the central and regional governments.

\footnotetext{
155 Montesserat Guibernau, above n 146, at 15.

156 Josep Desquens, above n 151.

${ }^{157}$ Spanish Constitution of 1978.

${ }^{158}$ Spanish Constitution of 1978, Art. 2.

${ }^{159}$ Montesserat Guibernau, above n 146, at 12.
} 
The stubborn position of the Spanish government is largely due to the nature of the Spanish state. Along with Catalonia, there are a number of other distinct ethnic, linguistic and cultural groups within Spain that constitute territorially concentrated national groups. The Basque Country in Northern Spain, and Galicia in the North West, for example, have similarly strong independence movements. The precedent set by Catalonian independence could have significant implications for the territorial integrity of Spain, and in the most extreme, could lead to the break up of the state.

Is a Catalan secession claim legitimate?

Overall, the Catalonian secession claim does not appear to be legitimate. Although it meets the criteria of nationhood and has a territorial claim over the region, that claim is lessened by the relatively recent (1978) assent to continued participation in the re-constituted Spanish state. The region enjoys strong and increasing political and economic autonomy, and is thus internally selfdetermining on virtually every legislative matter. It currently has no remedial justification for urgent secession from Spain - the current Spanish regime has a good human rights record, and the cultural repression and human rights abuses of the past have been discontinued in the last 50 years. Economic complaints centered on the fiscal imbalance between the region and poorer parts of Spain such as Andalusia cannot alone justify secession. Although the Catalonian state may be viable, the Spanish government refuse to consent to independence, and a unilateral secession could have significant implications for the ongoing viability of the existing Spanish state. The implication of this for Catalonia and other secessionist movements within Spain is that without a sea change in attitude in Madrid, successful secession from Spain looks unlikely.

\section{A Eastern Ukraine}

\section{$1 \quad$ Nationhood / Claim to territory}

The regions of Eastern Ukraine have significant ethnic Russian populations - around 90\% of the total population - who are culturally, ethnically and linguistically different from the Ukrainian population. ${ }^{160}$ The region is currently in conflict between Pro-Russian separatist forces and Ukrainian government supporters. The separatist forces, with the support of the Russian Government, seek the secession of Eastern Ukraine into a new state termed Novorossiya (literally

\footnotetext{
${ }^{160}$ Kalyanaram Raman "Novorossiya, Nowhere to Hide - Stalemate in Ukraine" (August 15 2014) Kalpatraman 〈http://kalpatraman.hubpages.com/hub/Novorossiya-Nowhere-to-Hide-Stalemate-in-Ukraine〉.
} 
New Russia). ${ }^{161}$ The territory claimed by Novorossiyan separatists takes in the Donetsk Oblast and Luhansk Oblast, regions of Eastern Ukraine - both of which border Russia and voted to secede from the Ukraine in May 2014. ${ }^{162}$ The area was part of the Russian Empire, but under the Soviet Union was incorporated into the Ukrainian Soviet Socialist Republic. ${ }^{163}$ Following the break up of the Soviet Union in 1990, it remained territory of the Ukraine. Supporters of independence suggest that the territory is wrongfully claimed by Ukraine. ${ }^{164}$

The constitutional structure of the Ukraine does not currently give significant autonomy to regions. Regions in Ukraine (with the exception of the autonomous republic of Crimea) are divided into oblasts (regional administrative units) but legislative decisions are generally made at state level. ${ }^{165}$ The Russian population in Eastern Ukraine complain that the central government is not representative of Ukraine, and many in the region disagree with a number of decisions and policies of the central government, particularly relating to Ukraine's relations with the West. ${ }^{166}$

\section{$3 \quad$ Treatment at the hands of the state}

Reports of the treatment of the Russian population in Eastern Ukraine are mixed. Although there are no suggestions of gross human rights abuses, Kalyanearaman Raman suggests that the culture of the Russian population is not properly respected by the government: ${ }^{167}$

The Constitution of Ukraine guarantees the development, use and protection of Russian and other minority languages spoken in the country (Crimean Tatar, Krymchak, Karaim and Urum). In practice, however, the resurgence of Ukrainian nationalism following the country's independence from the yoke of the erstwhile USSR (after over 70 years) and the consequent ascendancy of the Ukrainian language, entailed the relegation of the Russian language to a

\footnotetext{
${ }^{161}$ Al Jazeera "Putin seeks 'statehood' talks on East Ukraine" (31 August 2014) Al Jazeera News <http://www.aljazeera.com/news/europe/2014/08/putin-seeks-statehood-talks-east-ukraine2014831154441912942.html>.

${ }^{162}$ Interfax America "Ukraine Crisis: Donetsk, Luhansk People's Republics declare independence from Ukraine" (16 May 2014) Interfax: Russia \& CIS Business and Investment Weekly

$<$ http://search.proquest.com/docview/1530418789?accountid=14782>.

${ }^{163}$ Kalyanaram Raman, above n 160.

${ }^{164}$ Kalyanaram Raman, above n 160.

165 Office of the United Nations High Commissioner for Human Rights "Report on the Human Rights Situation in Ukraine (15 April 2014) United Nations 〈http://www.un.org.ua/images/stories/Report_15_April_2014_en.pdf >.

${ }^{166}$ Office of the United Nations High Commissioner for Human Rights, above n 165.

${ }^{167}$ Kalyanaram Raman, above n 160.
} 
secondary position and an increasingly growing feeling of alienation among the Russianspeaking segment of the population.

April and May United Nations Monitoring reports cited a number of human rights issues within Ukraine (including excessive use of force and breaches of the rights to freedom of assembly and expression), however, generally they considered that "the legislative and policy environment was conducive to the protection of minority rights, including cultural rights". ${ }^{68}$ Since then, international media reports and continued UN Monitoring suggest the human rights situation in Eastern Ukraine has deteriorated significantly in 2014. ${ }^{169}$ Those reports, tend to suggest that many of the abuses are at the hands of the separatist rebel forces and are the result of the increasing conflict, rather than the Ukrainian government. ${ }^{170}$

The concerns around the creation of the new state are largely that it would be simply an extension of Russia, rather than an independent state in itself. ${ }^{171}$ The independent Novorossiya would likely be economically reliant on the support of Russia, rather than viable in its own right. ${ }^{172}$ There are also concerns at international level about the treatment of citizens within an independent or Russian state. While under Ukrainian control there were some concerns about human rights, and Ukraine does not have an impeccable human rights record, ${ }^{173}$ such concerns have escalated as a result of the secessionist conflict. ${ }^{174}$ In the UN August Monitoring report, significant concerns were raised about the separatist rebels. The report highlighted that "in addition to the fighting, armed groups continued to commit killings, abductions, physical and psychological torture, ill treatment, and other serious human rights abuses and violations of international humanitarian law". 175

\footnotetext{
168 Office of the United Nations High Commissioner for Human Rights "Report on the Human Rights Situation in Ukraine (15 May 2014) United Nations <http://www.un.org.ua/images/stories/Report_15_May_2014_en.pdf > at 18.

169 See, for example Tom Miles and Robert Evans "UN Monitors warn on human rights in East Ukraine, Crimea" (16 May 2014) Reuters <http://uk.reuters.com/article/2014/05/16/uk-ukraine-crisis-un-idUKKBN0DW0VN20140516>.

170 Tom Miles and Robert Evans, above n 169.

${ }^{171}$ Al Jazeera, above n 161.

172 Kalyanaram Raman, above n 160.

${ }^{173}$ See generally, Office of the United Nations High Commissioner for Human Rights, above n 165; Office of the United Nations High Commissioner for Human Rights, above n 168; Office of the United Nations High Commissioner for Human Rights "Report on the Human Rights Situation in Ukraine (15 June 2014) United Nations <http://www.ohchr.org/Documents/Countries/UA/HRMMUReport15June2014.pdf>; Office of the United Nations High Commissioner for Human Rights "Report on the Human Rights Situation in Ukraine (15 July 2014) United Nations <http://www.ohchr.org/Documents/Countries/UA/Ukraine Report_15July2014.pdf >; Office of the United Nations High Commissioner for Human Rights "Report on the Human Rights Situation in Ukraine (17 August 2014) United Nations <http://www.un.org.ua/images/stories/OHCHR_Ukraine 5th report.pdf $>$.

${ }^{174}$ Kalyanaram Raman, above n 160; Office of the United Nations High Commissioner for Human Rights "Report on the Human Rights Situation in Ukraine (17 August 2014) United Nations <http://www.un.org.ua/images/stories/OHCHR_Ukraine_5th_report.pdf > at 4.

175 Office of the United Nations High Commissioner for Human Rights, above n 174, at 4.
} 
Should the territory come under the proxy control of Russia, it is relevant that the human rights record of Russia (even towards the Russian population) is not better than that of the Ukraine. ${ }^{176}$ There are thus very valid concerns that under Russian control the treatment of both the minority and majority populations of Donetsk Oblast and Luhansk Oblast would deteriorate.

The Ukrainian government is firmly opposed to the secession of Novorossiya, and Ukrainian troops are fighting the separatists. ${ }^{177}$ Ukraine is concerned that the territory will become an extension of Russia and eventually be annexed to the Russian state, and furthermore that Russia will continue to attempt to increase its territory. ${ }^{178}$

Is the Novorossiyan secession claim legitimate?

Despite having declared its 'independence' in May 2014, “The area of Novorossiya is still internationally considered as sovereign territory of the Ukrainian state." ${ }^{179}$ Kalyanaraman Raman writes that: "no country has recognized the claim of Donetsk and Luhansk to independence, other than South Ossetia, a breakaway part of Georgia and which, itself, has very limited, and disputed, recognition." 180

Having considered the criteria for legitimacy, it is clear that Novorossiya does not have a legitimate secession claim. Although the Russian population does have potentially valid complaints about the lack of autonomy afforded to the Eastern regions, and the treatment of their cultural institutions and language, these complaints would be better dealt with through less extreme mechanisms of selfdetermination: for example federalization and autonomy arrangements, such as those afforded to Scotland and Catalonia. It is not yet clear that such options have been exhausted with the Ukrainian government to justify complete independence, and in fact recently there have been indications from the Ukrainian government that special status would be afforded to the region. ${ }^{181}$ For example, draft

\footnotetext{
${ }^{176}$ See generally Human Rights Watch "World Report 2014: Russia” (n.d.) Human Rights Watch <http://www.hrw.org/world-report/2014/country-chapters/russia >.

177 Anna Nemtsova "Novorossiya is coming apart at the seams" (August 15 2014) Foreign Policy <http://www.foreignpolicy.com/articles/2014/08/15/novorossiya is coming apart at the seams>.

178 Anna Nemtsova, above n 177.

179 Kalyanaram Raman, above n 160.

${ }^{180}$ Kalyanaram Raman, above n 160.

${ }^{181}$ See for example, Al Jazeera "Ukraine Leader pledges more autonomy for east" (10 September 2014) Al Jazeera <http://www.aljazeera.com/news/europe/2014/09/ukraine-poroshenko-autonomy-east-2014910163640362480.html>;
} 
changes to the Ukrainian constitution have proposed "the decentralization of power as well as enhanced protection of minority rights". ${ }^{182}$ Furthermore, there are concerns about the viability of the proposed state, and the degree to which it will exist as an extension of Russian territory.

\section{Conclusion}

Secession claims are not sufficiently dealt with at international law. Similarly theoretical analyses of the moral justifications for secession widely differ, with little scholarly agreement on, for example, whether there is a primary right to secede, a remedial right only, or no right to secede at all. Having reviewed the scholarly discussions around legal, moral and constitutional legitimacy of secession, this paper has developed five criteria that, taken together, can form an assessment of the overall legitimacy of a secession claim: (1) nationhood and claim to territory; (2) self-determination and autonomy; (3) treatment at the hands of the state; (4) viability of the proposed state ; and (5) position of the existing state. Applying these criteria to three very different but equally topical possible secession claims - Scotland from the United Kingdom, Catalonia from Spain, and Novorossiya from Ukraine - the interplay between these criteria is demonstrated. As secession is an extreme response, and necessarily involves interference with the territorial integrity of the existing state, there will only be a small number of claims with potential legitimacy - essentially those where there is either consent of the existing state, or an urgent remedial justification, and where both the proposed and existing state will be viable after the secession.

The development of a set of universal criteria for assessing the legitimacy of a claim is a crucial step in dealing with secession in the modern international environment. Identifying the five crucial areas of assessment goes some way to addressing the deficiencies with the international legal approach to questions of secession and statehood. It is the author's view that from here, further work and reform is required. There is a need for: (1) clear guidelines for who is eligible for secession; (2) agreement at international level as to when a legitimate claim will exist; and (3) a mechanism for adjudicating claims. In this paper I have suggested that secession should only be available to those who constitute a 'nation', and that should be assessed against the five criteria above. The legitimacy criteria developed in this paper take into account the scope of scholarly discussion on the issue and allow determination of which secession claims should be considered legitimate at international law. Something more is needed, in the form of adjudication, to address the "significant force" of secession movements in international law and politics. Various 
suggestions have been made as to how and where such claims could be adjudicated. Allen Buchanan, for example, has suggested that secession could be dealt with through an expansion of existing UN bodies. ${ }^{183} \mathrm{He}$ suggested that the 'United Nations Special Committee on Decolonisation' could be expanded to include non-colonial secession claims. ${ }^{184}$ Michael Seymour also suggested that existing international bodies could sufficiently manage the task. ${ }^{185}$ For example, the International Court of Justice functions could be expanded to allow it to consider such questions referred to it, or a similar judicial body could be created for adjudication purposes. ${ }^{186}$ Further work and international agreement is required on this question.

183 Allen Buchanan, above n 102, at 222.

184 Allen Buchanan, above n 102, at 222.

${ }^{185}$ Michael Seymour "Peoples, self-determination and secession" (ASEN Seminars 2012, London, 23 February 2012 ).

${ }^{186}$ Michael Seymour, above n 185. 


\section{Bibliography}

A Cases

$1 \quad$ International Court of Justice

Accordance with international law of the unilateral declaration of independence in respect of Kosovo (Advisory Opinion) (2010) available online at International Court of Justice <www.icjcij.org>.

\section{$2 \quad$ Canada}

Reference re Secession of Quebec [1998] 2 S.C.R. 217.

\section{B Legislation}

\section{$1 \quad$ United Nations}

Statute of the International Court of Justice, 18 April 1946.

\section{$2 \quad$ United Kingdom}

Scotland Act 1998 (UK).

Scotland Act 1998 (Modification of Schedule 5) Order 2013 (UK) (S.I. 2013/242).

$3 \quad$ Spain

Spanish Constitution of 1978.

\section{$4 \quad$ Ethiopia}

Constitution of the Federal Democratic Republic of Ethiopia, 21 August 1995.

C Books and Chapters in Books 
Harry Beran "A democratic theory of political self-determination for a new world order " in Percy B Lehning (ed.) Theories of Secession (Routledge, London, 1998).

Allen Buchanan Secession: the Morality of Political Divorce from Fort Sumter to Lithuania and Quebec (Westview Press, USA, 1991).

Allen Buchanan Justice, legitimacy and self-determination: moral foundations for international law (Oxford University Press, Oxford, 2003).

Allen Buchanan "The Quebec Secession Issue: Democracy, Minority Rights, and the Rule of Law" in Macedo and Buchanan Secession and Self-Determination (2003, NYU Press: NOMOS XLV, New York).

Montserrat Guibernau Nationalisms: the Nation-State and Nationalism in the Twenty-first Century (Cambridge, Polity, 1996).

Albert O. Hirschman “Exit, Voice, and Loyalty” (1970, Harvard University Press, Cambridge).

Miroslav Jovanović The Economics of European Integration (Edward Elgar Publishing, UK, 2013).

Prof Marcelo Kohen (ed) Secession. International Law Perspectives (Cambridge University Press, Cambridge, 2006).

John Locke, Second Treatise of Civil Government (Hackett Publishing Co, Cambridge, 1980). David Miller "Secession and the principle of nationality" in Margaret Moore (ed) National Selfdetermination and secession (Oxford University Press, Oxford, 2003).

Margaret Moore National Self-Determination and Secession (1998, Oxford University Press, United Kingdom).

Margaret Moore (ed) National Self-determination and Secession (Oxford University Press, Oxford, 2003).

Stephen Neuff (ed) Hugo Grotius on The Law of War and Peace: Student Edition (Cambridge University Press, Cambridge, 2012).

Kai Nielsen "Liberal Nationalism and Secession” in Margaret Moore (ed) National Selfdetermination and secession (Oxford University Press, Oxford, 2003).

Wayne Norman "Domesticating Secession" (2003) in Macedo and Buchanan Secession and SelfDetermination (2003, NYU Press: NOMOS XLV, New York).

Wayne Norman "The Ethics of Secession as Regulation of Secessionist Politics" in Margaret Moore (ed) National Self-Determination and Secession (Oxford, Oxford University Press, 1998).

Diane F Orentlicher "International responses to separatist claims: are democratic principles relevant?" in Macedo and Buchanan Secession and Self-Determination (2003, NYU Press: NOMOS XLV, New York). 
Aleksander Pavkovic and Peter Radan (eds) The Ashgate Research Companion to Secession (Ashgate, Australia, 2011).

Daniel Philpott "Self-Determination in Practice" in Margaret Moore (ed) National Selfdetermination and Secession (Oxford University Press, Oxford, 2003).

David Raic Statehood and the Law of Self-determination (Brill, Netherlands, 2002).

Malcolm N. Shaw International Law (5th ed., Cambridge University Press, Cambridge, 2003).

Timothy Sisk Power sharing and international mediation in ethnic conflict (United States Institute of Peace, USA, 1996).

Christian Walter, Antje von Ungern-Sternberg, and Kavus Abushov (eds) Self-Determination and Secession in International Law (Oxford University Press, Oxford, 2014).

Christopher Heath Wellman A Theory of Secession (Cambridge University Press, Cambridge, 2005).

D Journal Articles

Anonymous "Kosovo: the Problem” (1998) 22/4 World Eagle 31.

Lea Brilmayer "Secession and Self-Determination: A Territorial Interpretation" (1991) 16 Yale Journal of International Law 177.

Lea Brilmayer "Commentaries on Lea Brilmayer, Secession and Self-Determination: A Territorial Interpretation: One Decade Later" (2000). Faculty Scholarship Series. Paper 2439.

<http://digitalcommons.law.yale.edu/fss_papers/2439>.

Allen Buchanan “Toward a Theory of Secession” (1991) 101/2 Chicago Law Review 322.

Allen Buchanan “Theories of secession” (1997) 26/1 Philosophy and Public Affairs 31.

Amandine Catala "Remedial Theories of Secession and Territorial Justification" (2013) 44/1

Journal of Social Philosophy 74.

David Copp "International Law and Morality in the theory of secession" (1998) 2/3 The Journal of Ethics 219.

F Deitrich "The status of Kosovo - reflections on the legitimacy of secession" (2010) 3/2 Ethics and Global Politics 123.

Montesserat Guibernau "Prospects for an Independent Catalonia" (2013) International Journal of Politics, Culture and Society 27/1, 5-23.

Sander Happaerts “Does Autonomy Matter” (2012) 45/1 Canadian Journal of Political Science 141. 
Avishai Margalit and Joseph Raz "National Self-determination” (1990) 87(9) Journal of Philosophy 439.

David Miller "Territorial Rights: Concept and Justification” (2012) 60/2 Political Studies 252. Charlotte Mueller "Secession and Self-Determination - Remedial Right Only Theory scrutinised" (2012) 7 POLIS Journal 283.

Alexander Nicoll "Scotland's vote on Independence" (2014) 56/33 Survival: Global Politics and Strategy 105.

Anthony Pavkovic "Recursive Secession in Former Yugoslavia: too Hard a case for Theories of Secession" (2000) 48/3 Political Studies 485.

Michael Seymour "Secession as a Remedial Right” (2007) 50 Inquiry 395.

Samuel J Spector, "Western Sahara and the Self-Determination Debate" (2009) Middle East Quarterly 33.

Cass Sunstein “Constitutionalism and Secession” (1991) 58/2 The University of Chicago Law Review 633.

Steven Tierney "Legal Issues surrounding the Referendum on Independence for Scotland" (December 2013) 9/3 European Constitutional Law Review 359.

Christopher Heath Wellman “A Defense of Secession and Political Self-Determination” (1995) 24/2 Philosophy and Public Affairs 142.

\section{E Government Materials}

James Crawford and Alan Boyle, "Opinion: Referendum on the Independence of Scotland International Law Aspects" published in annex to UK Government Devolution and the implications of Scottish Independence (UK Government, London, 2013).

Scottish Government "Agreement between the United Kingdom Government and the Scottish Government on a referendum on independence for Scotland" (15 October 2012) Scottish Government <http://www.scotland.gov.uk/Resource/0040/00404789.pdf>

Scottish Government "Monthly Economic brief - July 2014” (31 July 2014) The Scottish Government $\langle$ http://www.scotland.gov.uk/Topics/Economy/Monthly-Economic-Brief $>$. Scottish Government "The Scottish Independence Bill: A Consultation on an Interim Constitution for Scotland" (2014) Scottish Government <http://www.scotland.gov.uk/Resource/0045/00452762.pdf $>$. Scottish Government "FAQ" (2014) Scotland's Referendum <http://www.referendum.scot>. 


\section{F Reports}

Office of the United Nations High Commissioner for Human Rights "Report on the Human Rights Situation in Ukraine (15 April 2014) United Nations

<http://www.un.org.ua/images/stories/Report 15 April 2014 en.pdf $>$.

Office of the United Nations High Commissioner for Human Rights "Report on the Human Rights Situation in Ukraine (15 May 2014) United Nations

<http://www.un.org.ua/images/stories/Report_15_May_2014_en.pdf $>$.

Office of the United Nations High Commissioner for Human Rights "Report on the Human Rights Situation in Ukraine (15 June 2014) United Nations

<http://www.ohchr.org/Documents/Countries/UA/HRMMUReport15June2014.pdf>.

Office of the United Nations High Commissioner for Human Rights "Report on the Human Rights Situation in Ukraine (15 July 2014) United Nations

<http://www.ohchr.org/Documents/Countries/UA/Ukraine_Report_15July2014.pdf>.

Office of the United Nations High Commissioner for Human Rights "Report on the Human Rights Situation in Ukraine (17 August 2014) United Nations

<http://www.un.org.ua/images/stories/OHCHR_Ukraine_5th_report.pdf $>$.

\section{G Internet Resources}

Al Jazeera "Putin seeks 'statehood' talks on East Ukraine" (31 August 2014) Al Jazeera News <http://www.aljazeera.com/news/europe/2014/08/putin-seeks-statehood-talks-east-ukraine2014831154441912942.html>.

A1 Jazeera "Ukraine Leader pledges more autonomy for east" (10 September 2014) A1 Jazeera <http://www.aljazeera.com/news/europe/2014/09/ukraine-poroshenko-autonomy-east2014910163640362480.html>.

Badie, Bertrand, Berg-Schlosser, Morlino "International Encyclopedia of Political Science" (2011) SAGE knowledge.

BBC News "Ukraine Crisis: Poroshenko offers rebels more autonomy" (10 September 2014) BBC News <http://www.bbc.com/news/world-europe-29140593 $>$.

Lea Brilmayer "Why the crimean referendum is illegal" (14 March 2014) The Guardian <http://www.theguardian.com/commentisfree/2014/mar/14/crimean-referendum-illegalinternational-law>.

Allen Buchanan "Secession” (Feb 7 2003, revised Apr 5 2013) Stanford Encyclopedia of Philosophy <http://plato.stanford.edu/entries/secession/>. 
Tom Christiano "Democracy” (Jul 27 2006) Stanford Encyclopedia of Philosophy <http://plato.stanford.edu/entries/democracy/>.

Josep Desquens “Europe's stateless nations in the era of globalization: the case for Catalonia's Secession from Spain” (2003) The Bologna Center Journal of International Affairs 〈http://www.jhubc.it/bcjournal/articles/desquens.cfm $>$.

Martin Fletcher "The Birth of Kurdistan” (August 2013) Prospect Magazine <http://www.prospectmagazine.co.uk/features/the-birth-of-kurdistan-martin-fletcher>.

Monteserrat Guibernau "The rise of secessionism in Catalonia has emerged out of the will to decide the region's political destiny as a nation" (2012) European Politics and Policy Blog <http://blogs.lse.ac.uk/europpblog/2012/05/29/catalonia-secession/>.

Human Rights Watch “World Report 2014: Russia” (n.d.) Human Rights Watch <http://www.hrw.org/world-report/2014/country-chapters/russia $>$.

Human Rights Watch “World Report Chapter: Serbia” (2010) Human Rights Watch 〈http://www.hrw.org/world-report-2010/serbia-1>.

Interfax America “Ukraine Crisis: Donetsk, Luhansk People's Republics declare independence from Ukraine" (16 May 2014) Interfax: Russia \& CIS Business and Investment Weekly $<$ http://search.proquest.com/docview/1530418789?accountid=14782>.

Urska Mavric "Rethinking the Right to Secession: A Democratic Theory Account" Central European University <www.etd.ceu.hu/2012/mavric_urska.pdf〉.

David McLean "Should I stay or should I go now? Secession and Self-Determination in International Law" (June 1995) Reocities < http://www.reocities.com/Athens/Agora/5465/Law/secession.html>.

Tom Miles and Robert Evans "UN Monitors warn on human rights in East Ukraine, Crimea" (16 May 2014) Reuters <http://uk.reuters.com/article/2014/05/16/uk-ukraine-crisis-unidUKKBNODWOVN20140516>.

Anna Nemtsova "Novorossiya is coming apart at the seams" (August 15 2014) Foreign Policy <http://www.foreignpolicy.com/articles/2014/08/15/novorossiya is coming apart at the seams >. Kalyanaram Raman "Novorossiya, Nowhere to Hide - Stalemate in Ukraine” (August 15 2014) Kalpatraman < http://kalpatraman.hubpages.com/hub/Novorossiya-Nowhere-to-Hide-Stalemate-inUkraine>.

The Economist “Centrifugal Spain: Umbrage in Catalonia” (Nov 24 2012) The Economist <http://www.economist.com/news/leaders/21567088-even-though-spectre-secession-unwelcomedistraction-spain-still-needs $>$. 
H Other Resources

Margaret Moore "Territorial Right and Secession: the problem of differential natural resource endowment" (unpublished) < http://eis.bris.ac.uk/ plcdib/territory/papers/Moore-

TerritorialRightsandSecession.pdf $>$.

Michael Seymour "Peoples, self-determination and secession" (ASEN Seminars 2012, London, 23 February 2012). 